\title{
Global sensitivity analysis of the GEOS-Chem chemical transport model: ozone and hydrogen oxides during ARCTAS (2008)
}

\author{
Kenneth E. Christian ${ }^{1}$, William H. Brune ${ }^{1}$, and Jingqiu Mao ${ }^{2}$ \\ ${ }^{1}$ Department of Meteorology and Atmospheric Science, Pennsylvania State University, University Park, PA, USA \\ ${ }^{2}$ Geophysical Institute and Department of Chemistry and Biochemistry, University of Alaska at Fairbanks, \\ Fairbanks, AK, USA \\ Correspondence to: Kenneth E. Christian (kec5366@psu.edu)
}

Received: 27 September 2016 - Discussion started: 11 October 2016

Revised: 27 January 2017 - Accepted: 13 February 2017 - Published: 17 March 2017

\begin{abstract}
Developing predictive capability for future atmospheric oxidation capacity requires a detailed analysis of model uncertainties and sensitivity of the modeled oxidation capacity to model input variables. Using oxidant mixing ratios modeled by the GEOS-Chem chemical transport model and measured on the NASA DC-8 aircraft, uncertainty and global sensitivity analyses were performed on the GEOSChem chemical transport model for the modeled oxidants hydroxyl $(\mathrm{OH})$, hydroperoxyl $\left(\mathrm{HO}_{2}\right)$, and ozone $\left(\mathrm{O}_{3}\right)$. The sensitivity of modeled $\mathrm{OH}, \mathrm{HO}_{2}$, and ozone to model inputs perturbed simultaneously within their respective uncertainties were found for the flight tracks of NASA's Arctic Research of the Composition of the Troposphere from Aircraft and Satellites (ARCTAS) A and B campaigns (2008) in the North American Arctic. For the spring deployment (ARCTAS-A), ozone was most sensitive to the photolysis rate of $\mathrm{NO}_{2}$, the $\mathrm{NO}_{2}+\mathrm{OH}$ reaction rate, and various emissions, including methyl bromoform $\left(\mathrm{CHBr}_{3}\right)$. $\mathrm{OH}$ and $\mathrm{HO}_{2}$ were overwhelmingly sensitive to aerosol particle uptake of $\mathrm{HO}_{2}$ with this one factor contributing upwards of $75 \%$ of the uncertainty in $\mathrm{HO}_{2}$. For the summer deployment (ARCTAS-B), ozone was most sensitive to emission factors, such as soil $\mathrm{NO}_{x}$ and isoprene. $\mathrm{OH}$ and $\mathrm{HO}_{2}$ were most sensitive to biomass emissions and aerosol particle uptake of $\mathrm{HO}_{2}$. With modeled $\mathrm{HO}_{2}$ showing a factor of 2 underestimation compared to measurements in the lowest $2 \mathrm{~km}$ of the troposphere, lower uptake rates $\left(\gamma_{\mathrm{HO}_{2}}<0.055\right)$, regardless of whether or not the product of the uptake is $\mathrm{H}_{2} \mathrm{O}$ or $\mathrm{H}_{2} \mathrm{O}_{2}$, produced better agreement between modeled and measured $\mathrm{HO}_{2}$.
\end{abstract}

\section{Introduction}

With rising temperatures, shrinking sea ice, and expanding emissions into the atmosphere from increased human development and biomass burning, the Arctic is experiencing rapid changes felt nowhere else on the globe. While the region is largely undeveloped, anthropogenic air pollution from Northern Hemisphere population centers in East Asia, Europe, and North America is regularly advected into the Arctic atmosphere, contributing to the "Arctic haze" (e.g., Barrie et al., 1981). Increasing oil and gas exploration and extraction, coupled with summertime shipping lanes through the region will make air pollution worse (Granier et al., 2006). A better understanding of atmospheric oxidation chemistry is needed in order to provide a scientific basis for a sound mitigation strategy to combat this likely deteriorating air quality.

Atmospheric oxidants are at the forefront of any air chemistry study because the lifetimes of most gaseous and particulate species are determined through oxidant reactions. The primary atmospheric oxidizers of interest are the hydroxyl radical $(\mathrm{OH})$, the hydroperoxyl radical $\left(\mathrm{HO}_{2}\right)$, collectively referred to as $\mathrm{HO}_{x}\left(\mathrm{HO}_{x} \equiv \mathrm{OH}+\mathrm{HO}_{2}\right)$, and ozone $\left(\mathrm{O}_{3}\right)$ (Levy II, 1971). Ozone, $\mathrm{OH}$, and $\mathrm{HO}_{2}$ are coupled in a cycle in which ozone photolysis leads to the creation of $\mathrm{OH}$, which then cycles with volatile organic compounds to create $\mathrm{HO}_{2}$, which then can react with nitric oxide (NO) to ultimately produce ozone and recycle $\mathrm{OH}$. While this cycle appears to be well known and documented, models still fail in describing atmospheric composition (e.g., Emmons et al., 2015). These model shortcomings are usually attributed to 
errors in the chemical reaction rates, emissions, or meteorology (e.g., Chen et al., 1997; Fischer et al., 2014; Jaeglé et al., 2005; Kinnison et al., 2007).

A useful tool for examining and attributing sources to these model shortcomings is sensitivity and uncertainty analyses. In performing sensitivity analyses, there are two basic approaches: local and global. Local sensitivity analysis involves varying model inputs one at a time around a given point in input space while holding all other model inputs constant. This method assumes at least locally linear inputoutput relationships. Global sensitivity analyses on the other hand, involve the simultaneous perturbation of all the model inputs allowing for the interactions between inputs to be analyzed as well (Rabitz and Aliş, 1999). Global sensitivity analysis does not assume that the input and output have a linear local relationship and in fact can test the sensitivity of the output factors to the co-variation of two or more input factors. Global sensitivity analysis is preferred over local sensitivity analysis for complex models (Saltelli et al., 2008) and applies well to global chemical transport models (CTMs), such as the GEOS-Chem (Goddard Earth Observing SystemChemistry) model used in this study, that can have nonlinear interactions in the chemical kinetics, emissions, and meteorology.

Previous sensitivity studies using GEOS-Chem tended to use local sensitivity methods despite the known nonlinearity of the underlying chemical processes and subsequent interactions with meteorological and emission factors. To combat these nonlinearities, a common strategy in sensitivity studies involves the perturbation of model factors across a smaller sample of the input space (e.g., Fiore et al., 2009; Wu et al., 2009). While useful in ascertaining sensitivities for individual factors, this method cannot provide a complete picture of the modeled uncertainty as the entire input space is not sampled. In other sensitivity studies GEOS-Chem has been analyzed for its sensitivity to meteorological models and factors (e.g., Wu et al., 2007; Heald et al., 2010) and both biogenic (Fiore et al., 2005; Mao et al., 2013b) and anthropogenic emissions (e.g., Fiore et al., 2002; Martin et al., 2003; Auvray and Bey, 2005; Jaeglé et al., 2005; Guerova et al., 2006). While helpful, these local sensitivity studies were limited to perturbing a small set of similar input factors, so it is possible that some important input factors or interactions may have been missed.

This study covers National Aeronautics and Space Administration's (USA) (NASA's) Arctic Research of the Composition of the Troposphere from Aircraft and Satellites (ARCTAS) campaign (2008) (Jacob et al., 2010). The impetus of the campaign was to better understand the complex interactions between atmospheric composition, the environment, and climate in the North American Arctic and was split into three sub-campaigns, ARCTAS-A (spring), ARCTAS-CARB (California - not included in this study), and ARCTAS-B (summer). ARCTAS-A sought to better understand the chemical processes during the polar sunrise, when anthropogenic pollution is at its annual maximum and halogen chemistry is active and was based in Fairbanks, Alaska (USA); Iqaluit, Nunavut (Canada); and Thule, Greenland. A point of emphasis of ARCTAS-B was characterizing the effects of biomass burning emissions from the forest fires ubiquitous during the Arctic summer and examining the chemistry within smoke plumes of varying age (Jacob et al., 2010). ARCTAS-B was based in Cold Lake, Alberta (Canada), and Thule, Greenland.

This study is different from previous sensitivity studies involving CTMs, specifically GEOS-Chem, because the quantity and diversity of perturbed inputs are greater. Through a global sensitivity analysis, we identify and quantify the sources of uncertainty for atmospheric oxidants and explore how these factors explain model-measurement differences. Presented here is a global sensitivity analysis of a global CTM allowing for the assessment of model uncertainties and determining the sensitivities of model outputs to chemistry, emissions, and meteorology input factors.

\section{Methods}

\subsection{GEOS-Chem}

The chemical transport model used for this study is GEOSChem. GEOS-Chem has been a valuable tool in understanding global air chemistry since its introduction into the literature (Bey et al., 2001) and is currently used by scores of institutions around the world for a wide ranging set of air chemical applications. This study uses the standard GEOS-Chem CTM (v9-02). For computational expediency, the model runs use a regridded horizontal resolution of $4^{\circ} \times 5^{\circ}$ and 47 hybrid vertical layers. While previous CTM studies have shown that coarse resolution elevates $\mathrm{OH}$ concentrations and ozone production rates, the error from resolution typically pales in comparison to those errors arising from chemistry, meteorology, and emissions (Wild and Prather, 2006). In our case, we found small differences (usually $<10 \%$ ) for ARCTAS-A and $\mathrm{B}$ between mean vertical profiles of ozone, $\mathrm{OH}$, and $\mathrm{HO}_{2}$ using either $4^{\circ} \times 5^{\circ}$ or $2^{\circ} \times 2.5^{\circ}$ resolutions and thus using the coarser resolution is adequate for this study. The following sections briefly describe the meteorology, emissions, and chemistry components of the model.

\subsubsection{Meteorology}

GEOS-Chem is driven by the Global Modeling and Assimilation Office's (GMAO) GEOS-5 (Goddard Earth Observing System) meteorological model. GEOS-5 has a native resolution of $0.5^{\circ} \times 0.666^{\circ}$ with 72 hybrid eta levels but is regridded to $4^{\circ} \times 5^{\circ}$ with 47 hybrid vertical levels for input into GEOS-Chem. There are about 60 GEOS-5 meteorological fields handled by GEOS-Chem. Mixing depths and surface meteorological fields, such as soil wetness, heat fluxes, and albedo have a $3 \mathrm{~h}$ temporal resolution. In contrast, 3-D fields, 
such as $u$ and $v$ wind components and temperature, have $6 \mathrm{~h}$ temporal resolution (Bey et al., 2001). Transport is handled by the semi-Lagrangian TPCORE algorithm (Lin and Rood, 1996).

Due to the lack of published uncertainties associated with the GEOS-5 meteorological data, we defined our meteorological uncertainties as the average monthly standard deviation of the difference between GEOS-5 and GEOS-4 meteorological fields for 2005, a year of overlap between the models. For relative and specific humidity, an uncertainty of $5 \%$, similar to Heald et al. (2010), was assumed. Cloud mass flux uncertainty was inferred from differences between GEOS-5, a single column model, and a cloud resolving model and set at a factor of 1.5 (Ott et al., 2009).

\subsubsection{Emissions}

GEOS-Chem includes emissions from a variety of anthropogenic, biogenic, and other emissions sources. For this study, the default emissions were generally used. In the following section we note exceptions to this and a more detailed description of the various emission inventories.

For biogenic emissions, this study used the default MEGAN 2.1 (Model of Emissions and Gases and Aerosols from Nature). Out of the nine species provided by MEGAN, isoprene emissions are dominant, accounting for about half of the biogenic volatile organic compound (VOC) emissions in GEOS-Chem. We assume a factor of 2 uncertainty for isoprene emissions (Guenther et al., 2012). Biomass emissions, a point of emphasis in the ARCTAS-B campaign, were supplied via the Global Fire Emissions Database 3 (GFED-3) (van der Werf et al., 2010). GFED-3 emissions were calculated every $3 \mathrm{~h}$. For both biomass and soil $\mathrm{NO}_{x}$ emissions we assume a factor of 3 uncertainty (Jaeglé et al., 2005). With biomass and soil emissions inventories having a large spread in estimates (e.g., Schumann and Huntrieser, 2007; Vinken et al., 2014), this relatively high uncertainty is not unreasonable.

For anthropogenic volatile organic compound (VOC) emissions, the model uses a combination of REanalysis of the TROpospheric chemical composition (RETRO), Emission Database for Global Atmospheric Research (EDGAR), and regional emissions inventories. RETRO was developed by the Netherlands Organisation for Applied Research (TNO). GEOS-Chem 9-02 uses 12 VOC species from RETRO (Reinhart and Millet, 2011). EDGAR v4.1 emissions (Olivier et al., 1996) are the default model for $\mathrm{NO}_{x}$ $\left(\mathrm{NO}_{x} \equiv \mathrm{NO}+\mathrm{NO}_{2}\right), \mathrm{CO}$, and $\mathrm{SO}_{x}\left(\mathrm{SO}_{x} \equiv \mathrm{SO}_{2}+\mathrm{SO}_{4}^{2-}\right)$ in GEOS-Chem. It has a resolution of $1^{\circ} \times 1^{\circ}$ and is available on a yearly basis. For many parts of the world, especially the developed world, this study used the default regional emissions datasets that overwrote the RETRO or EDGAR fields.

Lightning $\mathrm{NO}_{x}$ is emitted through the scheme developed by Price and Rind (1992) in which lightning frequency is parameterized based on cloud height and land cover type.
In this scheme, continental flash frequencies are higher than marine storms due to stronger storm updrafts observed over land. GEOS-Chem assumes a global total of $6 \mathrm{Tg} \mathrm{Nyr}^{-1}$ as per Martin et al. (2007) and Sauvage et al. (2007). For this study, the lightning $\mathrm{NO}_{x}$ emissions were rescaled to $6.3 \mathrm{Tg} \mathrm{Nyr}^{-1}$ with an assumed uncertainty of $\sim 25 \%$ consistent with more recent literature (Miyazaki et al., 2014). This uncertainty may be higher (Liaskos et al., 2015) but is not a major consideration in this domain given the low lightning frequency in the Arctic.

An important factor for any study of ozone is the stratospheric-tropospheric exchange (STE) of ozone. In GEOS-Chem, it is typically parameterized by the Linoz scheme (McLinden et al., 2000). To allow constant scaling of STE ozone, this study used instead the Synoz algorithm, which exchanges $500 \mathrm{Tg} \mathrm{yr}^{-1}$ of ozone through the tropopause (McLinden et al., 2000). The assumed uncertainty for this STE ozone is a factor of 2.

\subsubsection{Chemistry}

The standard chemical scheme in GEOS-Chem has more than 230 kinetic reactions. This study uses the Sparse-Matrix Vectorized Gear Code (SMVGEAR) chemical solver (Jacobson and Turco, 1994). These rates are updated periodically and are generally supplied by the Jet Propulsion Laboratory (JPL) (Sander et al., 2011), the International Union of Pure and Applied Chemistry (IUPAC) (Atkinson et al., 2007), or other recent literature. Uncertainties for chemical rate coefficients came from JPL (Sander et al., 2011). The standard photolysis scheme has 55 different reactions and uses the FAST-J algorithm (Wild et al., 2000) to calculate photolysis rates throughout the troposphere. Uncertainties for photolysis rates came from JPL's combined cross sectional and quantum yield uncertainties (Sander et al., 2011).

\subsubsection{Heterogeneous chemistry}

A major point of emphasis in this study is the effect of the treatment of heterogeneous chemistry in the model, especially the aerosol particle uptake of $\mathrm{HO}_{2}$ (referred to as gamma $\mathrm{HO}_{2}$ ). Gamma $\mathrm{HO}_{2}$ is defined as the fraction of $\mathrm{HO}_{2}$ consumed per collision with aerosol particles. Until recent work by Mao et al. (2013a) that proposed catalytic reactions involving copper and iron ions in aqueous aerosols, it was assumed aerosol uptake of $\mathrm{HO}_{2}$ would eventually lead to $\mathrm{H}_{2} \mathrm{O}_{2}$ production (e.g., Jacob, 1986). While $\mathrm{H}_{2} \mathrm{O}$ formation is a terminal sink for $\mathrm{HO}_{x}, \mathrm{H}_{2} \mathrm{O}_{2}$ can be photolyzed and return $\mathrm{HO}_{x}$ radicals back into the atmosphere. GEOS-Chem has had an inconsistent history in the treatment of $\mathrm{HO}_{2}$ aerosol uptake with both the rate and product of this reaction. Originally GEOS-Chem set $\gamma_{\mathrm{HO}_{2}}=0.1$ producing $\mathrm{H}_{2} \mathrm{O}_{2}$ (Jacob, 2000), and then $\mathrm{HO}_{2}$ uptake was eliminated from the model to better match tropical results (Sauvage et al., 2007) before the later implementation of Thornton et al.'s (2008) mechanism. 
On the upper end of values for gamma $\mathrm{HO}_{2}$, some studies have used $\gamma_{\mathrm{HO}_{2}}=1.0$ (Emmons et al., 2015). In the version of the model used in this study, $\mathrm{HO}_{2}$ heterogeneous aerosol uptake is parameterized by $\gamma_{\mathrm{HO}_{2}}=0.2$ (Jacob, 2000) yielding $\mathrm{H}_{2} \mathrm{O}$, a terminal reaction for $\mathrm{HO}_{2}$ (Mao et al., 2013a). Uncertainties for heterogeneous chemical factors came from JPL (Sander et al., 2011).

\subsection{Global sensitivity analysis}

The global sensitivity analysis method used in this study is the random sampling-high dimensional model representation (RS-HDMR) (Rabitz and Aliş, 1999; Li et al., 2001). RS-HDMR is an approach to the HDMR method in which the inputs are randomly sampled from their uncertainty distributions. This study employed a slight variation of the RSHDMR method in which, in lieu of randomly sampling the input space, it is sampled using a Sobol sequence (Sobol, 1976), a quasi-random number sequence. Using this sequence allows for more efficient sampling of the input space and quicker convergence of the RS-HDMR metamodel solution (Feil et al., 2009), an important advantage with the high computational costs associated with chemical transport models.

The HDMR method describes the model output as an expansion in terms of the input factors.

$$
\begin{aligned}
f(x) & =f_{0}+\sum_{i=1}^{n} f_{i}\left(x_{j}\right)+\sum_{1 \leq i \leq n} f_{i j}\left(x_{i}, x_{j}\right)+\ldots \\
& +f_{12 \ldots n}\left(x_{1}, \ldots, x_{n}\right)
\end{aligned}
$$

Here $f_{0}$ is the zeroth-order component, a constant equivalent to the mean (Eq. 2), $f_{i}$ is the first-order effect corresponding to the independent effect of the input $x_{i}$ on the output (Eq. 3), $f_{i j}$ corresponding to the second-order effect on the output of inputs $x_{i}$ and $x_{j}$ working cooperatively (Eq. 4), on down to the $n$ th-order effect on the output by all the inputs working cooperatively (Rabitz and Aliş, 1999).

$$
\begin{aligned}
& f_{0} \approx \frac{1}{N} \sum_{s=1}^{N} f\left(x^{s}\right) \\
& f_{i} \approx \sum_{r=1}^{k_{i}} \alpha_{r}^{i} \varphi_{r}^{i}\left(x_{i}\right) \\
& f_{i j}\left(x_{i}, x_{j}\right) \approx \sum_{p=1}^{l_{i}} \sum_{q=1}^{l_{j}} \beta_{p q}^{i j} \varphi_{p}^{i}\left(x_{i}\right) \varphi_{q}^{j}\left(x_{j}\right)
\end{aligned}
$$

Here $\varphi$ represents orthonormal polynomials; $k_{i}, l_{i}$, and $l_{j}$ represent the orders of the polynomials; and $\alpha$ and $\beta$ are constant coefficients.

When using the RS-HDMR approach, the component functions representing the different ordered effects are orthogonal to one another. Because of this property, the total variance can be decomposed into a sum of variances of each component function (e.g., Li et al., 2010; Chen and Brune, 2012). For example,

$$
\begin{aligned}
V(f(x)) & =\sum_{i=1}^{n} V\left(f_{i}\left(x_{i}\right)\right)+\sum_{1 \leq i \leq n} V\left(f_{i j}\left(x_{i}, x_{j}\right)\right)+\ldots \\
& +V\left(f_{12 \ldots n}\left(x_{1}, \ldots, x_{n}\right)\right),
\end{aligned}
$$

where $V\left(f_{i}\left(x_{i}\right)\right)$ represents the variance of the first-order effect due to the input $x_{i}$ and so forth. It is important to note that $f_{i}\left(x_{i}\right)$ (Eq. 3) is not necessarily best described by a firstorder polynomial. From this expansion of the variance, the sensitivity indices of each component can be found by normalizing Eq. (5) by the total variance. Should $\Sigma S_{i} \approx 1$, firstorder effects dominate and individual second-order effects do not need to be calculated.

$$
\begin{aligned}
& S_{i}=\frac{V\left(f_{i}\left(x_{i}\right)\right)}{V(f(x))} \\
& S_{i j}=\frac{\left(V\left(f_{i j}\left(x_{i}, x_{j}\right)\right)\right)}{(V(f(x)))}
\end{aligned}
$$

Due to the relatively long run time and the large number of inputs that go into the GEOS-Chem model, a Morris method sensitivity test (Morris, 1991) for the Arctic domain was completed before starting the RS-HDMR study. The Morris method, also known as the elementary effects method, is a computationally inexpensive method to qualitatively determine which model factors have effects that are negligible, linear, or nonlinear and has been used in conjunction with many previous HDMR studies (e.g., Ziehn et al., 2009; Chen et al., 2012; Lu et al., 2013). As suggested by Saltelli et al. (2008), we employed 10 trajectories and four discrete levels within the uncertainty distributions for sampling. Initially, 465 different model inputs were perturbed. In the name of computational expediency, the number of perturbed inputs was reduced to approximately the $25 \%$ most important factors for the remaining eight trajectories. As the Morris method tests were used to prescreen factors for inclusion into the RS-HDMR tests, this initial cull after two trajectories did not influence the factors chosen at the conclusion of the Morris method test.

After the Morris method tests were completed, we selected the 50 most influential factors for $\mathrm{HO}_{2}, \mathrm{OH}$, and ozone mixing ratios for the spatial domain corresponding to the ARCTAS mission. This limiting of the analysis to 50 factors is in line with Ziehn and Tomlin (2008b); however, they note that this pre-screening process may not be necessary if thresholds are implemented in constructing the HDMR metamodel to exclude unimportant factors. In addition to the 50 most influential factors, regional Canadian $\mathrm{NO}_{x}$ emissions from the criteria air contaminant (CAC) inventory, and methyl bromoform emissions were also included in our HDMR analysis. Methyl bromoform emissions were included in the HDMR tests due to the importance of halogen chemistry in the Arctic (e.g., Simpson et al., 2007). All the factors included in the RS-HDMR analysis are listed in Table 1. 
Table 1. Factors included in RS-HDMR analysis and their respective uncertainties. OC is organic carbon, $\mathrm{ALK}_{4}$ is lumped $\geq 4 \mathrm{C}$ alkanes, MP is methylhydroperoxide, and $\mathrm{MO}_{2}$ is methylperoxy radical. Uncertainties are expressed as multiplicative factors, except as noted in meteorological factors.

\begin{tabular}{|c|c|}
\hline Factor & Uncertainty $^{\mathrm{a}}$ \\
\hline \multicolumn{2}{|l|}{ Emissions } \\
\hline $\begin{array}{l}\text { Biomass } \mathrm{CO}, \mathrm{NH}_{3}, \mathrm{NO}_{x}, \mathrm{OC} \\
\text { Soil } \mathrm{NO}_{x}\end{array}$ & $3.0^{\mathrm{c}}$ \\
\hline $\begin{array}{l}\mathrm{CAC}(\mathrm{Canada}) \mathrm{NO}_{x} \\
\text { Methyl bromoform }\left(\mathrm{CHBr}_{3}\right) \\
\text { EDGAR NO} \\
\text { EMEP (European) } \mathrm{NO}_{x} \\
\text { EPA (USA) ALK },, \mathrm{CO}, \mathrm{NH}_{3}, \mathrm{NO}_{x} \\
\text { Streets (E. Asian) } \mathrm{CO}, \mathrm{NH}_{3}, \mathrm{NO}_{x}, \mathrm{SO}_{2} \\
\text { Ship NO} \mathrm{NO}_{x} \\
\text { Strat-trop. exchange } \mathrm{O}_{3}\end{array}$ & 2.0 \\
\hline $\begin{array}{l}\text { Isoprene } \\
\text { Lightning } \mathrm{NO}_{x}\end{array}$ & $\begin{array}{r}2.0^{\mathrm{d}} \\
1.25^{\mathrm{e}}\end{array}$ \\
\hline \multicolumn{2}{|l|}{ Kinetics } \\
\hline $\begin{array}{l}k[\mathrm{BrO}]\left[\mathrm{HO}_{2}\right] \\
k[\mathrm{BrO}]\left[\mathrm{NO}_{2}\right] \\
k\left[\mathrm{HNO}_{3}\right][\mathrm{OH}] \\
k\left[\mathrm{HO}_{2}\right]\left[\mathrm{HO}_{2}\right] \\
k\left[\mathrm{HO}_{2}\right][\mathrm{NO}] \\
k\left[\mathrm{MO}_{2}\right]\left[\mathrm{HO}_{2}\right] \\
k[\mathrm{MP}][\mathrm{OH}] \\
k\left[\mathrm{NO}_{2}\right][\mathrm{OH}] \\
k\left[\mathrm{O}_{3}\right]\left[\mathrm{HO}_{2}\right] \\
k\left[\mathrm{O}_{3}\right]\left[\mathrm{NO}^{2}\right] \\
k\left[\mathrm{O}_{3}\right]\left[\mathrm{NO}_{2}\right] \\
k[\mathrm{OH}]\left[\mathrm{CH}_{4}\right] \\
\end{array}$ & $\begin{array}{r}1.15 / 1.2^{\mathrm{b}, \mathrm{f}} \\
1.2^{\mathrm{f}} \\
1.2^{\mathrm{f}} \\
1.15 / 1.2^{\mathrm{b}, \mathrm{f}} \\
1.15^{\mathrm{f}} \\
1.3^{\mathrm{f}} \\
1.4^{\mathrm{f}} \\
1.3^{\mathrm{f}} \\
1.15^{\mathrm{f}} \\
1.1^{\mathrm{f}} \\
1.15^{\mathrm{f}} \\
1.1^{\mathrm{f}}\end{array}$ \\
\hline \multicolumn{2}{|l|}{ Photolysis } \\
\hline $\begin{array}{l}j\left[\mathrm{BrNO}_{3}\right] \\
j[\mathrm{BrO}] \\
j\left[\mathrm{H}_{2} \mathrm{O}_{2}\right] \\
j\left[\mathrm{HNO}_{3}\right] \\
j[\mathrm{HOBr}] \\
j[\mathrm{MP}] \\
j\left[\mathrm{NO}_{2}\right] \\
j\left[\mathrm{O}_{3}\right] \\
\end{array}$ & $\begin{array}{l}1.4^{\mathrm{f}} \\
1.4^{\mathrm{f}} \\
1.3^{\mathrm{f}} \\
1.3^{\mathrm{f}} \\
2.0^{\mathrm{f}} \\
1.5^{\mathrm{f}} \\
1.2^{\mathrm{f}} \\
1.2^{\mathrm{f}}\end{array}$ \\
\hline \multicolumn{2}{|l|}{ Meteorology } \\
\hline $\begin{array}{l}\text { Cloud fraction } \\
\text { Cloud mass flux } \\
\text { Relative humidity } \\
\text { Soil wetness } \\
\text { Specific humidity } \\
\text { Temperature }\end{array}$ & $\begin{array}{r}8.5 \%^{\mathrm{g}} \\
1.5^{\mathrm{h}} \\
5 \% \%^{\mathrm{i}} \\
8.8 \%^{\mathrm{g}} \\
5 \%^{\mathrm{i}} \\
1.8 \mathrm{~K}^{\mathrm{g}}\end{array}$ \\
\hline \multicolumn{2}{|l|}{ Heterogeneous } \\
\hline $\begin{array}{l}\text { Gamma } \mathrm{HO}_{2} \\
\text { Gamma } \mathrm{HOBr} \\
\text { Gamma } \mathrm{N}_{2} \mathrm{O}_{5} \\
\text { Gamma } \mathrm{NO}_{2} \\
\text { Henry's law } \mathrm{HOBr}\end{array}$ & $\begin{array}{r}3.0^{\mathrm{f}} \\
3.0^{\mathrm{f}} \\
1.4^{\mathrm{f}} \\
3.0^{\mathrm{f}} \\
10.0^{\mathrm{f}}\end{array}$ \\
\hline
\end{tabular}

\subsubsection{Uncertainties}

After determining the factors to include in the HDMR test, the next step was to create the distributions from which to sample. Uncertainties for all the factors are listed in Table 1. Lognormal distributions were used for all distributions, except those for temperature, soil wetness, relative humidity, and cloud fraction, for which normal distributions were used. Standard deviations for the lognormal uncertainty distributions were determined by $\sigma=f-1$, where $f$ is the published uncertainty factor and $\sigma$ is the standard deviation of the distribution to be sampled, similar to Stewart and Thompson (1996). To ensure $\sim 95 \%$ of the quasi-random samples would be within the published uncertainty bounds and reflecting the $2 \sigma$ range JPL uses to incorporate chemical kinetic data and inferred from emissions uncertainties, these standard deviations were then halved before creating the distributions.

With the uncertainty distributions created, a Sobol sequence (discarding the first 512 sets of values as spin-up) was created to quasi-randomly sample these distributions and perturb the model. To ensure model perturbations had time to spread and reach a new global equilibrium, a 9-month spinup period was employed before the first flights in April 2008. The ensemble was limited to 512 model runs. While previous implementations of the RS-HDMR to box models used thousands of runs (e.g., Chen and Brune, 2012), recent use of the method with a land surface model shows reliable results with as few as 256 runs (Lu et al., 2013). Likewise, we found little difference in results between 512 and 256 model runs, but have included all 512 in this study.

\subsubsection{Calculation of sensitivity indices}

Graphical user interface HDMR (GUI-HDMR) was used to calculate all the sensitivity measures and analyze the inputoutput behavior of the model (Ziehn and Tomlin, 2009). This MATLAB software package is freely available through http://www.gui-hdmr.de. For use within the software, the values of the inputs were rescaled according to their respective percentiles within the uncertainty distributions. We employed the correlation method provided in the GUI-HDMR software (Kalos and Whitlock, 1986; Li et al., 2003), a variance reduction method. In using the correlation method, the construction of the RS-HDMR expansion becomes an iterative process using an analytical reference function. With this method, as noted in Li et al. (2003), the accuracy of the RS-HDMR expansion increases without a corresponding increase in ensemble size, a valuable advantage considering the expensive nature of running CTMs.

\subsection{Measurements}

For comparison to the model, we also used measurements collected aboard the NASA DC-8 aircraft. $\mathrm{OH}$ and $\mathrm{HO}_{2}$ 
measurements came from Pennsylvania State University's Airborne Tropospheric Hydrogen Oxides Sensor (ATHOS) (Faloona et al., 2004). ATHOS uses laser-induced fluorescence (LIF) to measure $\mathrm{HO}_{x}$ mixing ratios. The National Center for Atmospheric Research's (NCAR, USA) selected-ion chemical ionization mass spectrometer (SICIMS) and peroxy radical chemical ionization mass spectrometer (PeRCIMS) also measured $\mathrm{OH}$ and $\mathrm{HO}_{2}$ respectively aboard the DC-8. Comparisons between the methods showed good agreement during the campaign (Ren et al., 2012). For the purposes of our analysis, only ATHOS measurements are considered. Ozone observations aboard the DC-8 were measured by NCAR using the chemiluminescence method (Weinheimer et al., 1994).

Since ARCTAS, interferences have been found in the measurements of both $\mathrm{OH}$ (Mao et al., 2012) and $\mathrm{HO}_{2}$ (Fuchs et al., 2011). The $\mathrm{OH}$ interference can be anywhere from 20 to $300 \%$ of the actual ambient $\mathrm{OH}$, while the $\mathrm{HO}_{2}$ interference is typically less than a factor of 2 . Both interferences require the presence of alkenes or aromatics and so are limited to planetary boundary layer environments in which these volatile organic compounds are common. Interferences in the free troposphere and over much of the Arctic will be negligible.

\subsection{Data manipulation}

To directly compare the model ensemble to the aircraft observations, modeled results were output in one-minute intervals along the DC-8 flight track using the Planeflight option within GEOS-Chem. To match the modeled flight track, we averaged the aircraft observation data over 1 min intervals and excluded observations from the stratosphere. For our flight-by-flight HDMR analyses, average mixing ratios along the flight track were used as the output of interest in GUI-HDMR. For vertical profiles, modeled and measured flight track data were binned and averaged in $1 \mathrm{~km}$ increments, excluding the transit flights (flights $3,11,16$, and 24). While it is a concern that the modeled representation of the flight tracks may misrepresent spatially or temporally synoptic or mesoscale features important to the abundances of the studied species, these differences are likely small when averaged over each flight, and especially when averaged across all modeled flights.

\section{Results}

Given the seasonal differences between Arctic spring and summer in both meteorology and emissions, and the differences between the mission objectives between ARCTAS-A and ARCTAS-B, the results are separated by their respective season. During both ARCTAS-A and ARCTAS-B, the NASA DC-8 sampled the troposphere at a variety of heights ranging from near surface to the lower reaches of the strato-

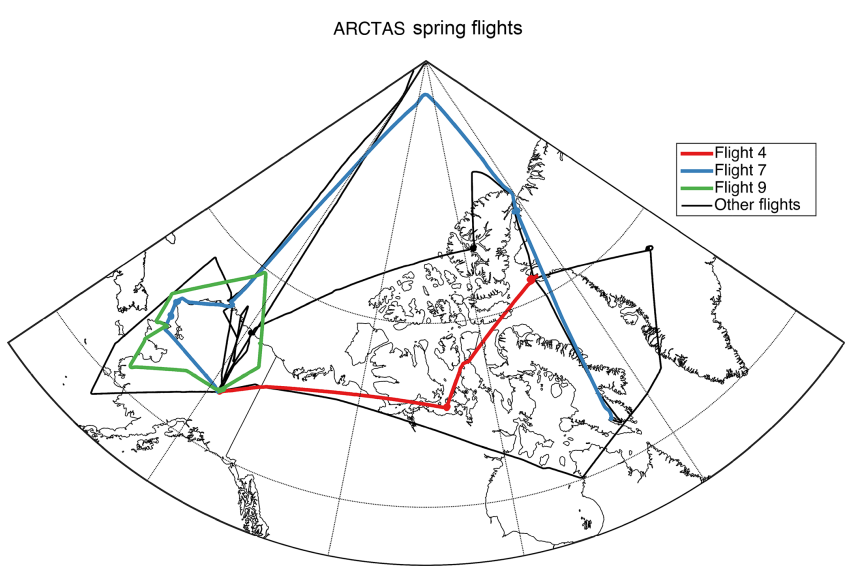

Figure 1. Map of ARCTAS-A flights over the North American Arctic. Highlighted flights correspond to flight data results analyzed in Fig. 3.

sphere, providing a fairly representative view of the Arctic troposphere over this domain for the times corresponding to these flights.

\subsection{ARCTAS-A (spring 2008)}

\subsubsection{Uncertainty analysis}

Across the modeled ensemble, ozone has relatively low uncertainty $(6.8 \%, 1 \sigma$ confidence) reflecting the low ozone production rates within the domain during ARCTAS-A (Fig. 1). In contrast to ozone, we found both $\mathrm{OH}$ and $\mathrm{HO}_{2}$ to have much higher uncertainty across the model ensemble with $\mathrm{OH}$ and $\mathrm{HO}_{2}$ both having $1 \sigma$ uncertainties of around $27 \%$. Figure 2 shows this uncertainty spread vertically. For ARCTAS-A, uncertainties and sensitivities were generally uniform with altitude across the model ensemble for ozone and $\mathrm{HO}_{x}$.

\subsubsection{Vertical profiles}

Figure 2 shows mean vertical profiles binned per kilometer for the spring deployment (Fig. 1). Ozone was consistently underpredicted by the model at all altitudes except near the surface and showed little variation across the ensemble in modeled ozone. This profile roughly follows what was observed with the $\mathrm{NO}_{2}$ profiles with $\mathrm{NO}_{2}$ being underpredicted by the model except for near the surface (Fig. S1 in the Supplement). The lack of significant in situ ozone production in April over the domain could partially explain the small variation in modeled mixing ratios among ensemble members. Similar to Mao et al. (2010), OH mixing ratios were low, in the tenths of one ppt, and showed a consistent model underestimation for the lower and middle troposphere with better agreement above $\sim 6 \mathrm{~km}$, although the limit of detection for the $\mathrm{OH}$ measurement is $\sim 10^{5} \mathrm{~cm}^{-3}$. Across the model ensemble there is general agreement between measured and 


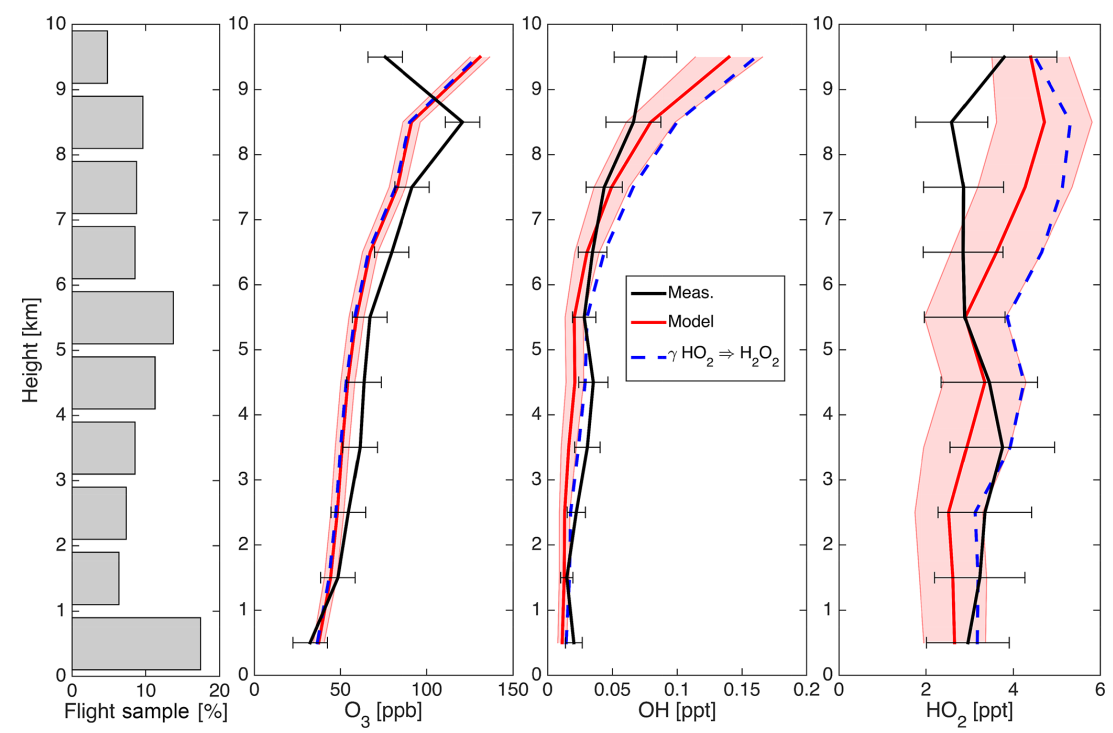

Figure 2. Vertical profiles of mean modeled (red) and measured (black) ozone, $\mathrm{OH}$, and $\mathrm{HO}_{2}$ for ARCTAS-A flight data binned by kilometer. Gray bar graph shows percent of flight data within each vertical bin. Shaded regions represent $1 \sigma$ of model ensemble; error bars on measurements are uncertainty at $1 \sigma$ confidence. Blue line represents gamma $\mathrm{HO}_{2}$ producing $\mathrm{H}_{2} \mathrm{O}_{2}$ rather than $\mathrm{H}_{2} \mathrm{O}$.

modeled $\mathrm{HO}_{2}$ within the vertical column as measured values are mostly within the first standard deviation of modeled results. This is different from Mao et al. (2010), in which GEOS-Chem showed a consistent overestimation of $\mathrm{HO}_{2}$. Above $7 \mathrm{~km}$, modeled $\mathrm{HO}_{2}$ is higher than measured, by upwards of a factor of 2, similar to Mao et al. (2010). These results are consistent with improvement in modeled characterization of $\mathrm{HO}_{2}$ aerosol particle uptake as aerosol concentrations are highest in the lowest few kilometers of the atmosphere and very low in the upper reaches of the troposphere.

\subsubsection{Sensitivity analysis}

Figure 3 shows the first-order results of the HDMR analysis for the average tropospheric mixing ratios along selected flight tracks for ozone, $\mathrm{OH}$, and $\mathrm{HO}_{2}$. For $\mathrm{HO}_{x}$ and ozone, the sensitivities are, with a minor few exceptions, altitude independent. The first-order sensitivity index for all factors are represented and are color coded by their respective category as defined in Table 1. In this sense, first-order effects describe each factor's individual contribution to the ensemble variance. The RS-HDMR component functions for each factor are not necessarily linear, and are in fact often best represented by second-degree and higher polynomials. GUI-HDMR calculates the optimal order for each HDMR polynomial using a least-squares method (Ziehn and Tomlin, 2008a). The missing portion of the pie graph represents second- and higher-order sensitivities. While not all flights are presented here, the three flights in Fig. 3 cover the geographic spread of the domain and are representative of the results seen among other spring flights.
For ozone, the sum of all the first-order effects was usually less than 0.90 , meaning that first-order effects explain close to $90 \%$ of the observed variance. Calculating meaningful second-order terms will require substantially more model runs.

For each spring flight, the photolysis of $\mathrm{NO}_{2}$ was the most influential factor for modeled ozone with sensitivity indices ranging from around 0.09 to 0.11 (mean 0.10 ). It is not surprising $\mathrm{NO}_{2}$ photolysis is a sensitive factor considering the photolysis of $\mathrm{NO}_{2}$ leads directly to ozone production; however, it is somewhat surprising given its rather low uncertainty $(20 \%)$ and the limited ozone production in the Arctic spring. Other most influential factors are the $\mathrm{NO}_{2}+\mathrm{OH}$ reaction (mean $S_{i}=0.083$ ), soil $\mathrm{NO}_{x}$ emissions (0.047), temperature (0.056), and methyl bromoform emissions (0.072). Sensitivity of ozone to methyl bromoform emissions is expected due to bromine compounds' ability to catalytically destroy ozone, especially early in the Arctic spring when sunlight returns allowing for halogen photochemistry to commence (e.g., Barrie et al., 1988). Tropospheric ozone depletion events arising via catalytically destructive halogen reactions were observed during the ARCTAS-A campaign, mainly below $1 \mathrm{~km}$ (Koo et al., 2012). The misrepresentation of nitrogen reservoirs $\left(\mathrm{NO}_{y}\right)$, specifically the overprediction of $\mathrm{HNO}_{3}$ (nitric acid) and underprediction of PAN (peroxyacetyl nitrate), has been a long-standing issue within GEOSChem (e.g., Alvarado et al., 2010; Fischer et al., 2014), so it is unsurprising we find GEOS-Chem to be sensitive to the $\mathrm{NO}_{2}+\mathrm{OH}$ reaction rate. However, with previous implementations of the RS-HDMR method to box models showing similar sensitivity to this reaction (Chen and Brune, 2012; 

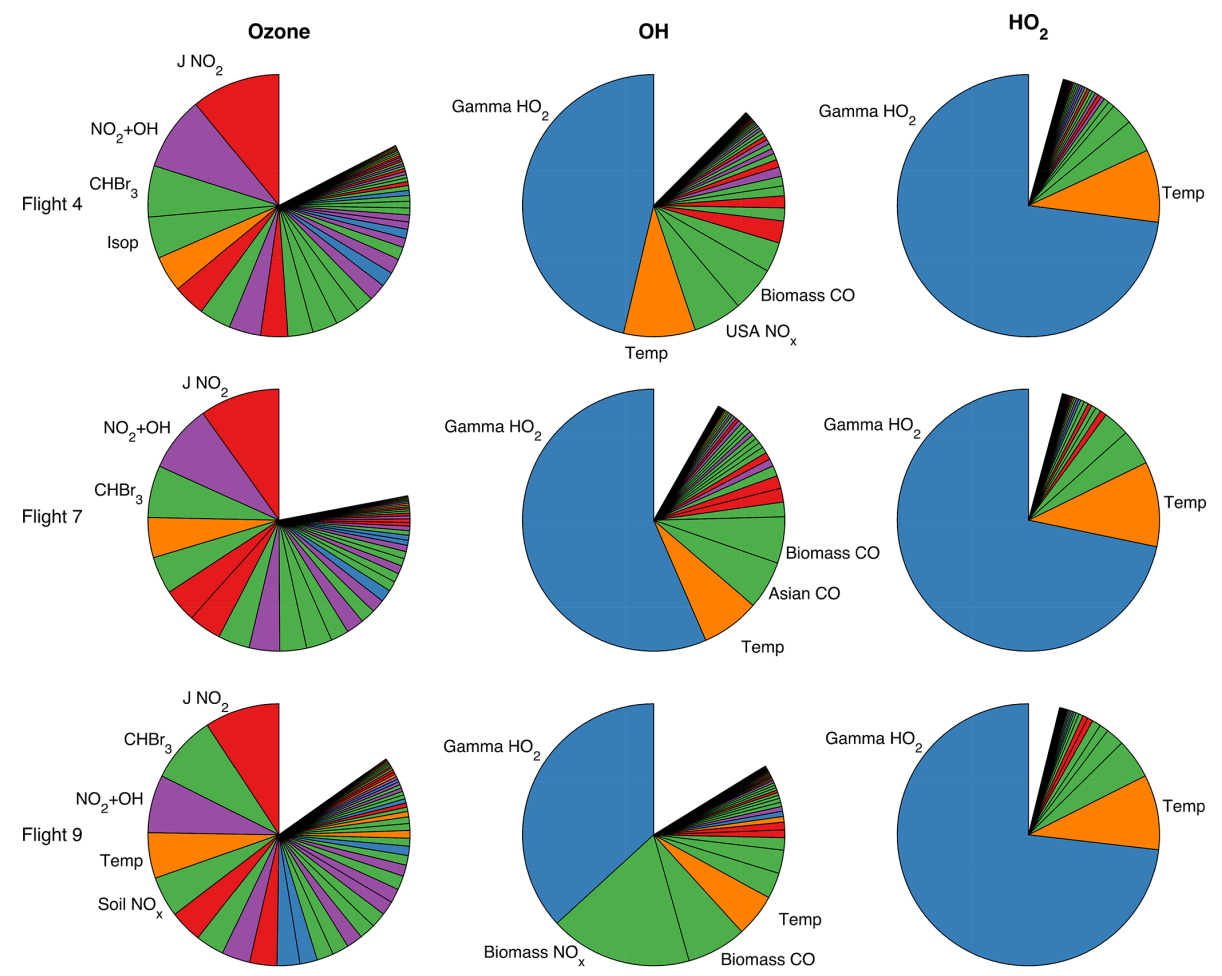

$\square$ Emissions $\square$ Kinetics $\square$ Photolysis $\square$ Meteorology $\square$ Heterogeneous

Figure 3. First-order sensitivity indices for average flight track $\mathrm{O}_{3}, \mathrm{OH}$, and $\mathrm{HO}_{2}$ for ARCTAS-A flights. Legend categories are defined in Table 1.

Chen et al., 2012), it does not appear to be a model-specific result.

$\mathrm{OH}$ mixing ratios were very low, in the tenths of one ppt. These low mixing ratios are expected considering the low sun angles in April over the Arctic and was noted in prior ARCTAS studies (Mao et al., 2010). Unlike ozone, $\sum S_{i} \approx$ 0.90 for most modeled flights, meaning first-order effects describe the vast majority of the model uncertainty. For all the flights, aerosol particle uptake of $\mathrm{HO}_{2}\left(\right.$ gamma $\left.\mathrm{HO}_{2}\right)$ was the most influential factor, having $S_{i}$ values ranging from 0.37 to 0.58 (mean $S_{i}=0.49$ ). Temperature (0.071) and biomass $\mathrm{CO}(0.058)$ also routinely had $S_{i}$ values above 0.05 . Among emissions, Asian and biomass $\mathrm{NO}_{x}$ and $\mathrm{CO}$ contributed the most to the uncertainty. The influence of Asian emissions during ARCTAS-A has been noted previously (Jacob et al., 2010) and highlights the sensitivity of the Arctic region to the advection of anthropogenic pollution, especially during the winter and spring, when the thermal inversion and vertical stratification of the air in the Arctic troposphere is most pronounced (Stohl, 2006).

As with $\mathrm{OH}, \mathrm{HO}_{2}$ mixing ratios were also low, and firstorder effects dominated in the RS-HDMR metamodel, with $\sum S_{i}$ values ranging from 0.94 to 0.98 . Of the first-order effects, gamma $\mathrm{HO}_{2}$ was dominant, with $S_{i}$ values ranging from 0.60 to 0.76 (mean $S_{i}=0.71$ ). This suggests that around $71 \%$ of the uncertainty associated with modeled $\mathrm{HO}_{2}$ is due to uncertainties in gamma $\mathrm{HO}_{2}$. Temperature was the only other factor regularly having a sensitivity index greater than 0.05 (mean $S_{i}=0.10$ ).

Aerosol particle uptake of $\mathrm{HO}_{2}$ has been found in previous studies to be of particular importance in the Arctic (Martin et al., 2003; Mao et al., 2010). With low $\mathrm{NO}_{x}$ concentrations and temperatures, the $\mathrm{HO}_{2}$ lifetime in the Arctic spring is especially long when compared to the midlatitudes or tropics. Without terminating reactions with other $\mathrm{NO}_{x}$ or $\mathrm{HO}_{x}$ radicals, uptake by aerosols becomes a dominant loss of $\mathrm{HO}_{2}$.

Providing a broad view of the sensitivity results from ARCTAS-A, Fig. 4 shows the same analysis as Fig. 3 but averaged across all flights and summed by factor category as defined in Table 1. While ozone is most sensitive to emissions, chemical factors from kinetics and photolysis rates also contribute a large portion to the uncertainty. $\mathrm{OH}$ and $\mathrm{HO}_{2}$ are overwhelmingly sensitive to heterogeneous chemistry, particularly gamma $\mathrm{HO}_{2}$ as seen in Fig. 3 .

\subsection{ARCTAS-B (summer 2008)}

\subsubsection{Uncertainty analysis}

Compared to ARCTAS-A, ozone in ARCTAS-B (Fig. 5) saw higher uncertainty across the model ensemble $(12 \%, 1 \sigma$ confidence) compared to the spring $(6.8 \%)$. This is reflective of 

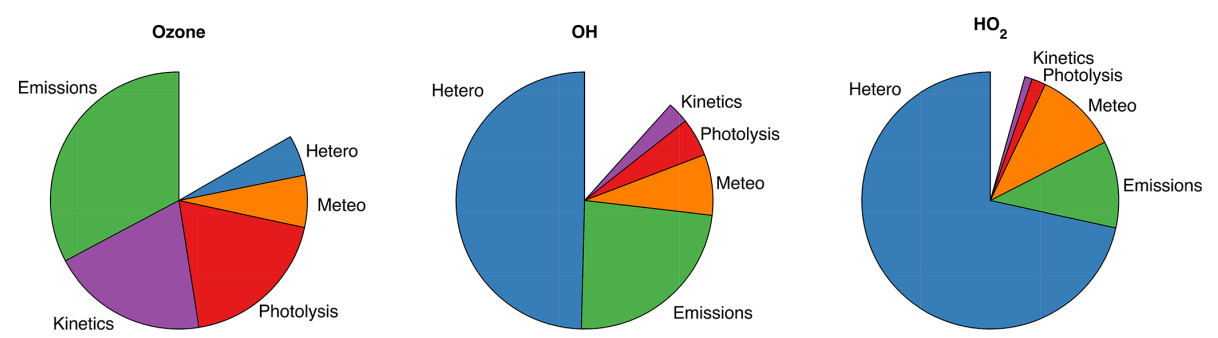

Figure 4. First-order sensitivity indices for modeled $\mathrm{O}_{3}, \mathrm{OH}$, and $\mathrm{HO}_{2}$ during ARCTAS-A averaged across all flights and binned by categories defined in Table 1.

the more photochemically active summertime in contrast to the spring. $\mathrm{OH}$ and $\mathrm{HO}_{2}$ uncertainties were similar to the spring with $\mathrm{OH}$ and $\mathrm{HO}_{2}$ uncertainties being 25 and $24 \%$ ( $1 \sigma$ confidence) respectively across the model ensemble.

\subsubsection{Vertical profiles}

Figure 6 shows the vertical profiles observed in ARCTAS-B for ozone, $\mathrm{OH}$, and $\mathrm{HO}_{2}$. As found in our ARCTAS-A results (Fig. 2) and also reported by Alvarado et al. (2010), we found GEOS-Chem to under-predict ozone for the middle troposphere by $10-20 \mathrm{ppb}$. Previously, Alvarado et al. (2010) posited mischaracterization of advection from the midlatitudes as a possible source of this error; however, not all chemical transport models run by GEOS-5 meteorology show this bias (Emmons et al., 2015). Other possible sources of error may come from mischaracterized chemistry or under-represented stratospheric transport. $\mathrm{OH}$ mixing ratios, as in ARCTAS-A, were low. Although well predicted by the model above $3 \mathrm{~km}$, OH was over-predicted below $3 \mathrm{~km}$ by around a factor of $2 . \mathrm{HO}_{2}$ saw the greatest modelmeasurement disagreement, with the model under-predicting $\mathrm{HO}_{2}$ by over a factor of 2 below $2 \mathrm{~km}$. This modeled underestimation of $\mathrm{HO}_{2}$ is noteworthy considering $\mathrm{HO}_{2}$ overestimation is much more common in air chemistry models (e.g., Mao et al., 2013a). Even when excluding measurements taken within smoke plumes as defined by HCN $>1000$ pptv, this underestimation decreases only by about $1 \mathrm{pptv}$ for the lower $2 \mathrm{~km}$ and remains about a factor of 2 . The simultaneous overestimate of $\mathrm{OH}$ and underestimate $\mathrm{HO}_{2}$ suggests the model is partitioning $\mathrm{HO}_{x}$ incorrectly and may be missing or under-representing $\mathrm{OH}$ reactions that would cycle $\mathrm{OH}$ to $\mathrm{HO}_{2}$. Another possible explanation for a portion of this overestimation of $\mathrm{HO}_{2}$ could be organic peroxy radical $\left(\mathrm{RO}_{2}\right)$ interference artificially elevating $\mathrm{HO}_{2}$ measurements (Fuchs et al., 2011), but this would likely not account for the factor of 2 underestimation.

\subsubsection{Sensitivity analysis}

First-order RS-HDMR sensitivity indices for tropospheric average ozone, $\mathrm{OH}$, and $\mathrm{HO}_{2}$ for along the path of flights 17, 19, and 22 (Fig. 5) are shown in Fig. 7. Figure 8 pro-

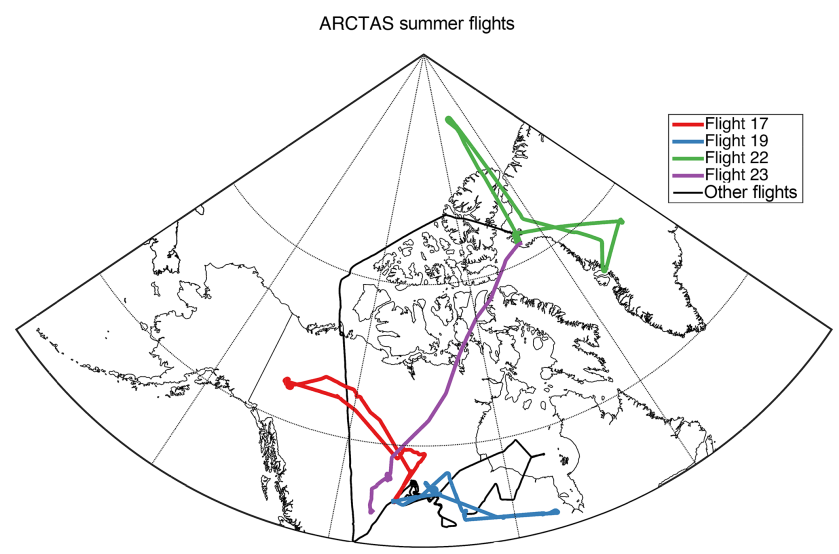

Figure 5. Map of ARCTAS-B deployment over the North American Arctic. Colored flights correspond to flight data results analyzed in Figs. 7 and 10.

vides a broad view of the sensitivities calculated across all the ARCTAS-B flights binned by category as shown in Table 1 . With a few exceptions, $\sum S_{i} \approx 0.90$ for all flight averaged ozone, $\mathrm{OH}$, and $\mathrm{HO}_{2}$ meaning first-order effects explain around $90 \%$ of the model uncertainty with higher-order input interactions responsible for the remaining uncertainty. Compared to ARCTAS-A, emissions are more influential across the board, especially from soils, biomass, and isoprene. Like ARCTAS-A, ARCTAS-B sensitivities were largely altitude independent.

For modeled ozone, mixing ratios were most sensitive to soil $\mathrm{NO}_{x}$ emissions with average $S_{i}$ across the flights around 0.181 , isoprene emissions (mean $S_{i}=0.081$ ), biomass CO and $\mathrm{NO}_{x}$ emissions (mean $S_{i}=0.069,0.089$ respectively), the $\mathrm{NO}_{2}+\mathrm{OH}$ reaction rate (mean $S_{i}=0.075$ ), and $\mathrm{NO}_{2}$ photolysis (mean $S_{i}=0.054$ ). The greater sensitivity to emissions in the summer compared to spring is almost certainly a result of biomass, soil, and isoprene emissions being much greater in Arctic summer than spring. These higher emissions coupled with higher sun angles allow for ozone production in the Arctic summer, unlike the very slow production in spring. Also, there is relatively low sensitivity to anthropogenic emissions, reflecting the remoteness of this domain and its relative pristine condition. 


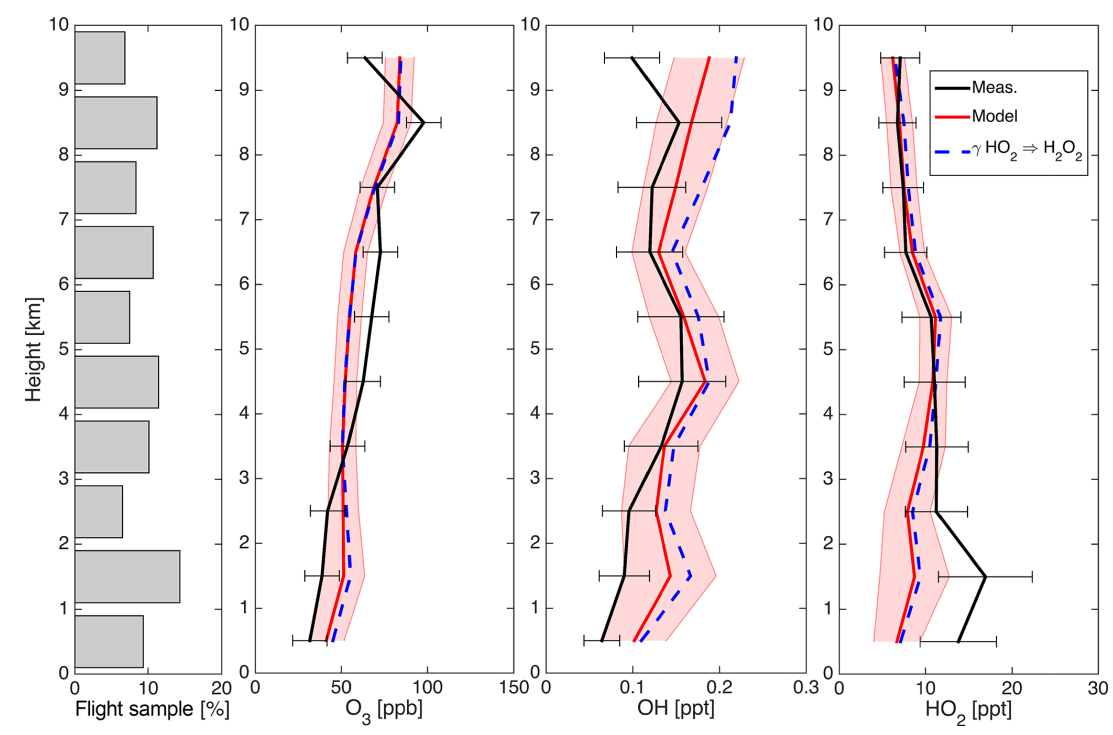

Figure 6. Vertical profiles of mean modeled (red) and measured (black) ozone, $\mathrm{OH}$, and $\mathrm{HO}_{2}$ for ARCTAS-B flight data binned by kilometer. Gray bar graph shows percent of flight data within each vertical bin. Shaded regions represent $1 \sigma$ of model ensemble; error bars on measurements are uncertainty at $1 \sigma$ confidence. The blue line represents gamma $\mathrm{HO}_{2}$ producing $\mathrm{H}_{2} \mathrm{O}_{2}$ rather than $\mathrm{H}_{2} \mathrm{O}$.
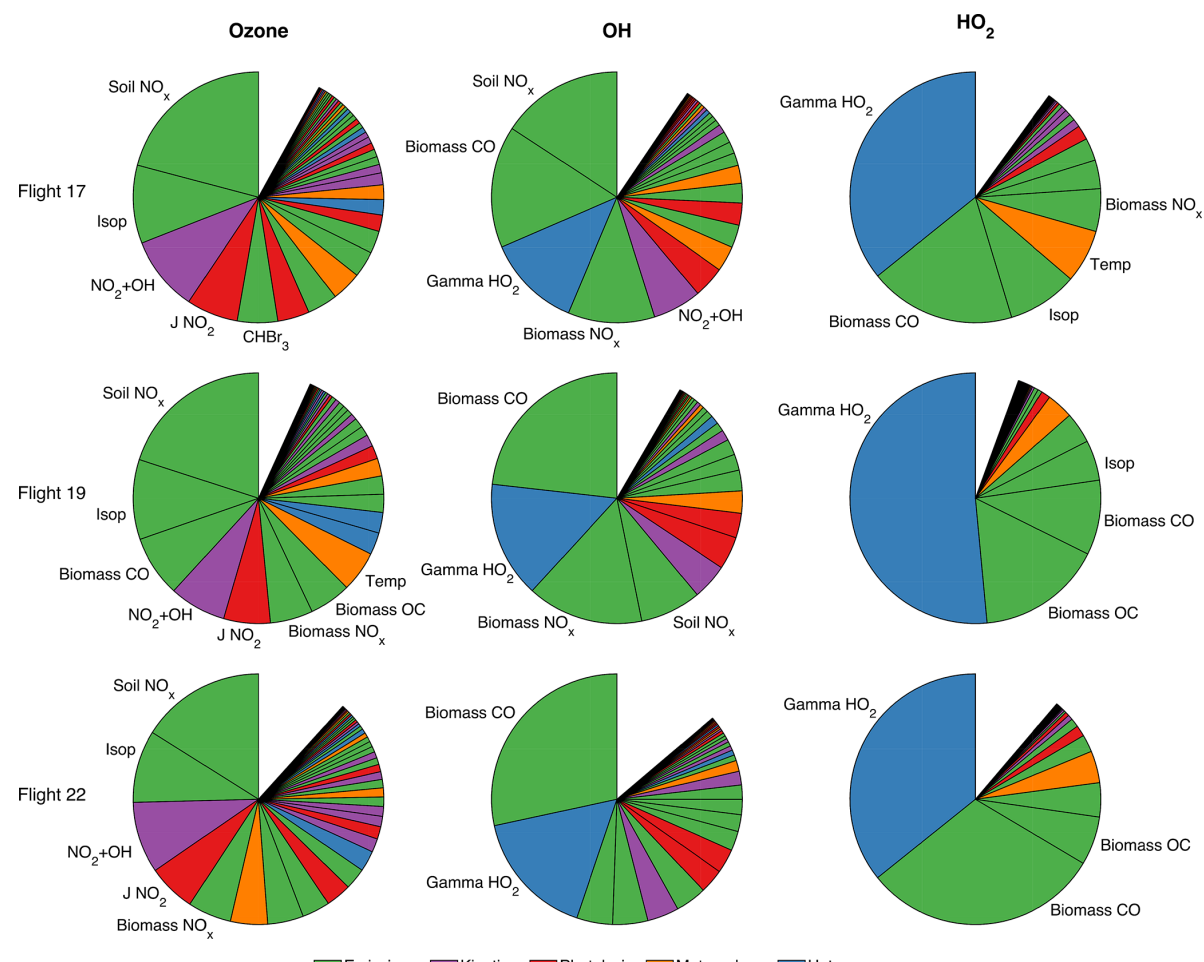

Figure 7. First-order sensitivity indices for average modeled $\mathrm{O}_{3}, \mathrm{OH}$, and $\mathrm{HO}_{2}$ along selected ARCTAS-B flights. Legend categories are defined in Table 1.

For $\mathrm{OH}$, soil and biomass $\mathrm{NO}_{x}$ emissions (mean $S_{i}$ across flights is 0.095 and 0.105 respectively), biomass $\mathrm{CO}$ emissions (mean $S_{i}=0.220$ ), and gamma $\mathrm{HO}_{2}$ (mean $S_{i}=$ 0.137 ) are most influential. As normal $\mathrm{OH}$ production requires the photolysis of ozone, $\mathrm{OH}$ being sensitive to the same emissions as ozone is expected. $\mathrm{OH}$ is sensitive to gamma $\mathrm{HO}_{2}$ as it represents a net sink of $\mathrm{HO}_{x}$ radicals.

Modeled $\mathrm{HO}_{2}$ mixing ratios were most sensitive to gamma $\mathrm{HO}_{2}$ and biomass $\mathrm{CO}$ and organic carbon emissions with mean $S_{i}$ across the flights of $0.405,0.167$, and 0.094 re- 

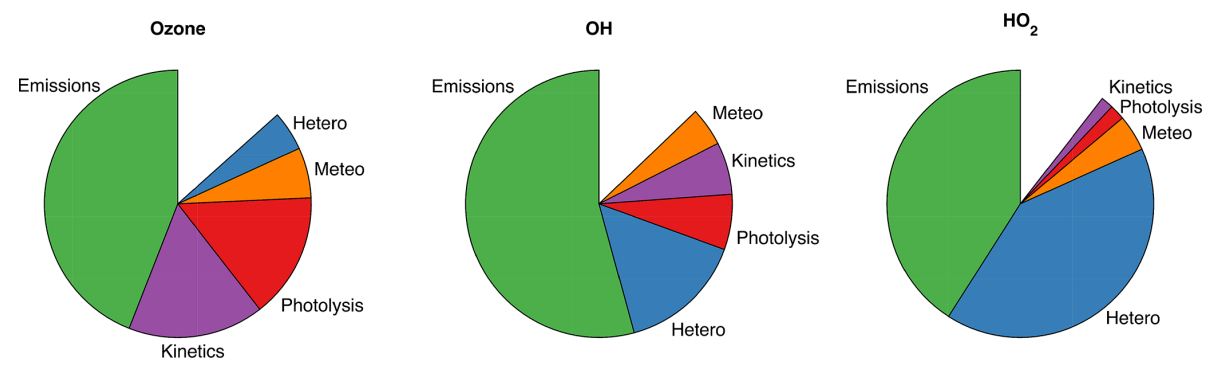

Figure 8. First-order sensitivity indices for modeled $\mathrm{O}_{3}, \mathrm{OH}$, and $\mathrm{HO}_{2}$ during ARCTAS-B averaged across all flights and binned by categories defined in Table 1.

spectively. This is qualitatively similar to the results from the spring; only the dominance of gamma $\mathrm{HO}_{2}$ on the total variance in modeled $\mathrm{HO}_{2}$ is lessened, but still prominent (mean $S_{i}=0.405$ in summer as opposed to 0.712 in spring). It is noteworthy that, even with reduced $\mathrm{HO}_{2}$ lifetimes in the Arctic summer compared to spring, $\mathrm{HO}_{2}$ still had such high sensitivity to gamma $\mathrm{HO}_{2}$.

Figure 8 shows an overview of the sensitivity results from ARCTAS-B averaged among all flights and summed by factor category as defined in Table 1. As found during ARCTASA (Fig. 4), ozone is most sensitive to emissions with chemical factors from kinetics and photolysis rates also contributing a large portion of the uncertainty. In contrast to the spring, $\mathrm{OH}$ and $\mathrm{HO}_{2}$ are most sensitive to emission factors in the summer; however, heterogeneous chemistry, especially gamma $\mathrm{HO}_{2}$, provides a large slice of the uncertainty as also noted in the spring (Fig. 4). In the case of summer $\mathrm{HO}_{2}$, gamma $\mathrm{HO}_{2}$ contributes individually almost as much as the sum of all emission factors to the model uncertainty.

To probe this disagreement between modeled and measured $\mathrm{HO}_{2}$ at lower altitudes seen in Fig. 6, we examined ensemble members with the best agreement between modeled and measured $\mathrm{HO}_{2}$ profiles. The ensemble members that matched the measured profile best had especially low gamma $\mathrm{HO}_{2}$ values. Figure 9 shows a comparison between the entire ensemble and ensemble members with gamma $\mathrm{HO}_{2}$ values in the lowest 10 percentiles of the uncertainty distribution $\left(\gamma_{\mathrm{HO}_{2}}<0.055\right)$. This model-measurement disagreement was not observed among all flights in the ARCTAS-B campaign. In fact, areas with lower aerosol abundances such as the northernmost flights, 22 and 23, showed general agreement between modeled and measured $\mathrm{HO}_{2}$ profiles (Fig. 10). Likewise, above $4 \mathrm{~km}$, the model performs very well in replicating the observed $\mathrm{HO}_{2}$ profile. Given its overwhelming importance in the RS-HDMR analysis, mischaracterization of gamma $\mathrm{HO}_{2}$ is a likely cause.

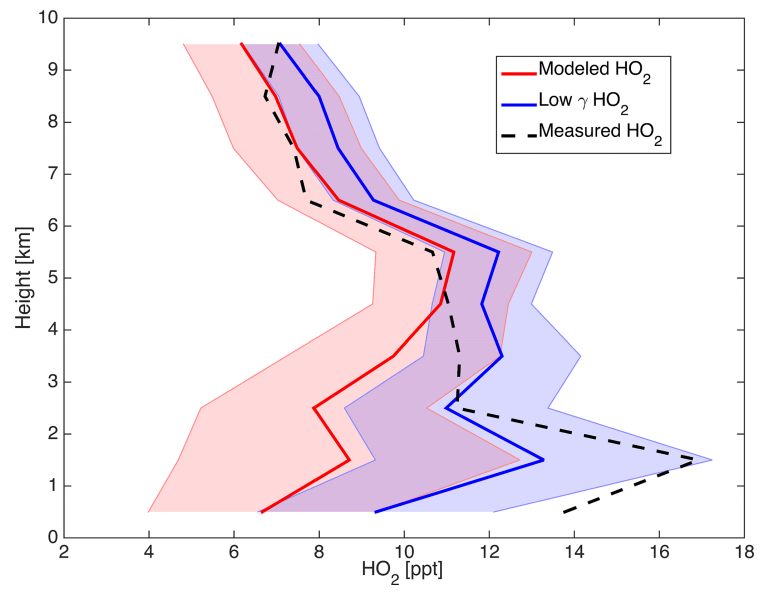

Figure 9. Vertical $\mathrm{HO}_{2}$ profile for ARCTAS-B flights. Shaded region represents $1 \sigma$ of the model ensemble. Blue line and region represents model runs with gamma $\mathrm{HO}_{2}$ values in the lowest $10 \%$ of the uncertainty distribution.
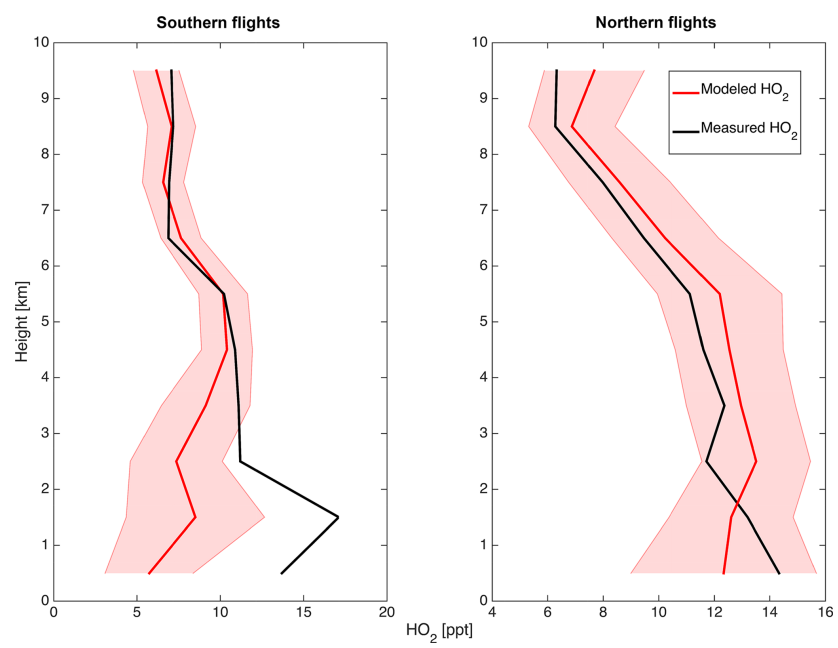

Figure 10. Modeled and measured $\mathrm{HO}_{2}$ profiles for ARCTAS-B flights. Shaded region represents $1 \sigma$ of model ensemble. Left represents flights $17,18,19,20$, and 21 . Right represents flights 22 and 23. 


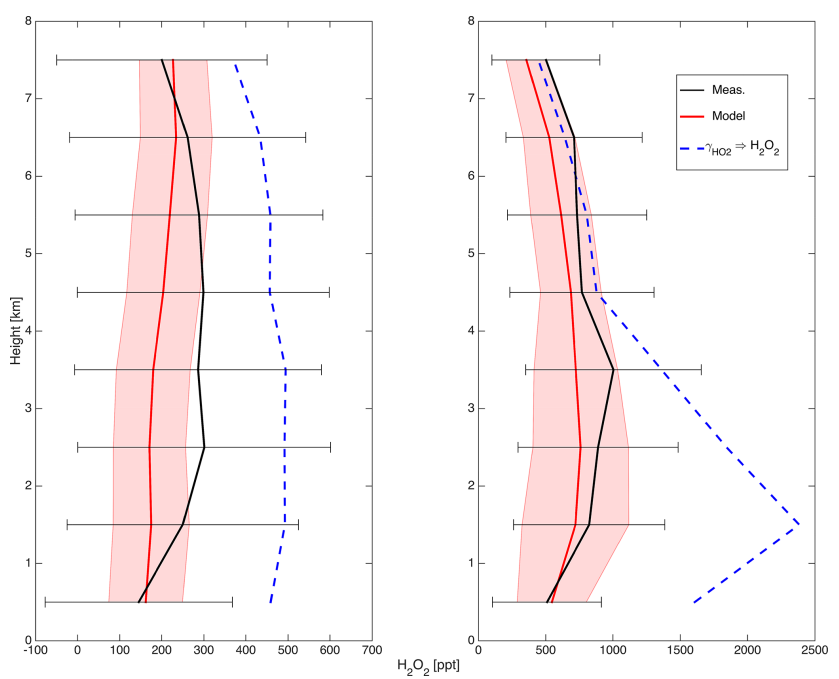

Figure 11. Vertical profile for $\mathrm{H}_{2} \mathrm{O}_{2}$ for flights during ARCTAS-A (left) and ARCTAS-B (right). Shaded region represents $1 \sigma$ of model ensemble. Error bars represent measurement uncertainty. Blue lines show gamma $\mathrm{HO}_{2}$ producing $\mathrm{H}_{2} \mathrm{O}_{2}$ rather than $\mathrm{H}_{2} \mathrm{O}$ in the model.

One possible cause of this disagreement is that $\mathrm{HO}_{2}$ aerosol particle uptake is leading to the formation of $\mathrm{H}_{2} \mathrm{O}_{2}$ instead of $\mathrm{H}_{2} \mathrm{O}$. Figure 11 shows the modeled and measured $\mathrm{H}_{2} \mathrm{O}_{2}$ profile for the ARCTAS-A and B flights. When altering the model for gamma $\mathrm{HO}_{2}$ to produce $\mathrm{H}_{2} \mathrm{O}_{2}$ instead of $\mathrm{H}_{2} \mathrm{O}\left(\gamma_{\mathrm{HO}_{2}} \Rightarrow 0.5 \mathrm{H}_{2} \mathrm{O}_{2}\right)$ (blue lines in vertical profiles in Figs. 2, 6, 11, S1, and S2), modeled $\mathrm{HO}_{2}$ increased throughout the vertical column by between 0.25 and $0.75 \mathrm{ppt}$ in the summer (Fig. 6) and between 0.5 and $1 \mathrm{ppt}$ in the spring (Fig. 2). In this same model run, $\mathrm{H}_{2} \mathrm{O}_{2}$ increased upwards of a factor of 3 , especially in the lowest $2 \mathrm{~km}$, taking modeled values a factor of 2 or greater higher than measurements (Fig. 11). It is noted that there was a large spread in $\mathrm{H}_{2} \mathrm{O}_{2}$ within the ensemble and a large uncertainty in the measured values $(50 \%+150 \mathrm{pptv})$. In the same test, we also find $\mathrm{CO}$ mixing ratios to decrease around $10 \mathrm{ppb}$ when gamma $\mathrm{HO}_{2}$ produces $\mathrm{H}_{2} \mathrm{O}_{2}$ instead of $\mathrm{H}_{2} \mathrm{O}$ (Figs. $\mathrm{S} 1$ and $\mathrm{S} 2$ ). As Arctic $\mathrm{CO}$ tends to be underestimated by chemical transport models (Fisher et al., 2010; Shindell et al., 2006), this decrease widens the model-measurement gap. While the difference in modeled $\mathrm{HO}_{2}$ between model runs having gamma $\mathrm{HO}_{2}$ 's product being either $\mathrm{H}_{2} \mathrm{O}$ or $\mathrm{H}_{2} \mathrm{O}_{2}$ is important during the spring when $\mathrm{HO}_{2}$ mixing ratios are lower, as Mao et al. (2010) and Fig. 2 show, this difference is less significant during the summer when $\mathrm{HO}_{2}$ mixing ratios are higher (Fig. 6). The difference between these model scenarios cannot be responsible for the difference between the observed and modeled mixing ratios in the lowest $2 \mathrm{~km}(\sim 7-8 \mathrm{ppt})$. This small effect suggests that, especially in the Arctic summer, concentrating on better characterization of the rate may be more important than the product for improving the agreement between measured and modeled $\mathrm{HO}_{x}$.

\section{Conclusions}

We have applied a RS-HDMR sensitivity analysis to a 3$\mathrm{D}$ chemical transport model. First-order sensitivity indices for the 52 perturbed model inputs have been calculated and shown in Figs. 3, 4, 7, and 8. For $\mathrm{OH}$ and $\mathrm{HO}_{2}$, we find general agreement between modeled and measured values when uncertainties in the measurements and uncertainties in model input factors are taken into account as evidenced by the overlap between the vertical model and measurement profiles (Figs. 2 and 6) with the notable exception of summertime $\mathrm{HO}_{2}$. In contrast, vertically binned modeled and measured ozone mixing ratios do not show as much overlap, especially in spring, for reasons that remain unclear. Modeled ozone was most sensitive to various emissions sources, especially soil $\mathrm{NO}_{x}$ and isoprene, and chemical factors, such as $j\left[\mathrm{NO}_{2}\right]$ and $k\left[\mathrm{NO}_{2}\right]+[\mathrm{OH}]$. Model sensitivities for $\mathrm{OH}$ and $\mathrm{HO}_{2}$ were dominated by aerosol particle uptake of $\mathrm{HO}_{2}$, especially in the spring, with a combination of biomass and soil emissions being also important, particularly in summer. While the sensitivity of oxidants to emissions is expected considering the high uncertainty in emissions inventories (factors of 23 ), it is noteworthy that chemical kinetic and photolysis rates were also responsible for a considerable portion of uncertainty even with their much lower published uncertainties, 20 and $30 \%$ for $j\left[\mathrm{NO}_{2}\right]$ and $k\left[\mathrm{NO}_{2}\right]+[\mathrm{OH}]$ respectively for example. This highlights the value in not only more certain emissions inventories but also more certain chemical kinetics rates.

$\mathrm{HO}_{2}$ aerosol particle uptake remains the dominant source of uncertainty in our analysis for $\mathrm{HO}_{x}$. From our ensemble, the best model-measurement agreement came with lower gamma $\mathrm{HO}_{2}$ values $\left(\gamma_{\mathrm{HO}_{2}}<0.055\right)$ than currently implemented in GEOS-Chem, regardless of the uptake product. Much attention has been given to determining the product of the aerosol particle uptake of $\mathrm{HO}_{2}$, and whether or not or in which instances $\mathrm{H}_{2} \mathrm{O}_{2}$ or $\mathrm{H}_{2} \mathrm{O}$ is produced. We find there is not a large difference in modeled $\mathrm{HO}_{2}$ between these two possibilities, especially in Arctic summer. In contrast, $\mathrm{H}_{2} \mathrm{O}_{2}$ is very sensitive to the product of the aerosol particle uptake of $\mathrm{HO}_{2}$ with $\mathrm{H}_{2} \mathrm{O}_{2}$ increasing upwards of a factor of 3 when the product is $\mathrm{H}_{2} \mathrm{O}_{2}$ instead of $\mathrm{H}_{2} \mathrm{O}$ (Fig. 11). Recent studies have expanded this question of $\mathrm{HO}_{2}$ uptake products from aqueous aerosols to smaller cloud droplets (Whalley et al., 2015). In particular, the analysis of Whalley et al. (2015) showed the Arctic region being especially sensitive to changes in $\mathrm{HO}_{2}$ uptake compared to the midlatitudes and tropics due to longer $\mathrm{HO}_{2}$ lifetimes in the Arctic. As shown in our results, this study also finds $\mathrm{HO}_{x}$ in the Arctic region to be particularly sensitive to gamma $\mathrm{HO}_{2}$. Because the Arctic is unique in its relatively low $\mathrm{HO}_{x}$ mixing ratios and long $\mathrm{HO}_{x}$ lifetimes compared to the midlatitudes and tropics, future research will be needed to determine whether or not gamma $\mathrm{HO}_{2}$ is as important globally as it is in the Arctic 
and whether or not aerosol particle uptake rates need to be reduced in GEOS-Chem.

Data availability. The measurements taken aboard the NASA DC-8 during ARCTAS are freely available through the NASA LaRC ARCTAS depository: https://www-air.larc.nasa.gov/cgi-bin/ ArcView/arctas. GUI-HDMR is available through contacting Tilo Ziehn or Alison Tomlin: http://www.gui-hdmr.de/. GEOS-Chem is available through contacting Harvard University (http://acmg. seas.harvard.edu/geos/). The model output in this study constitutes a very large dataset given the over 500 model runs in the ensemble, but is available by contacting the corresponding author (kec5366@psu.edu).

\section{The Supplement related to this article is available online at doi:10.5194/acp-17-3769-2017-supplement.}

Competing interests. The authors declare that they have no conflict of interest.

Acknowledgements. We could like to acknowledge NASA's Atmospheric Composition Campaign Data Analysis and Modeling program (ACCDAM) for funding this project (grant NNX14AP43G), Harvard University for managing and supporting GEOS-Chem, GEOS-Chem support for assistance, Andrew Weinheimer of NCAR for ozone measurements, Paul Wennberg and the CalTech group for $\mathrm{H}_{2} \mathrm{O}_{2}$ measurements, and two anonymous reviewers for their thoughtful input and constructive comments.

Edited by: D. Heard

Reviewed by: two anonymous referees

\section{References}

Alvarado, M. J., Logan, J. A., Mao, J., Apel, E., Riemer, D., Blake, D., Cohen, R. C., Min, K.-E., Perring, A. E., Browne, E. C., Wooldridge, P. J., Diskin, G. S., Sachse, G. W., Fuelberg, H., Sessions, W. R., Harrigan, D. L., Huey, G., Liao, J., Case-Hanks, A., Jimenez, J. L., Cubison, M. J., Vay, S. A., Weinheimer, A. J., Knapp, D. J., Montzka, D. D., Flocke, F. M., Pollack, I. B., Wennberg, P. O., Kurten, A., Crounse, J., Clair, J. M. St., Wisthaler, A., Mikoviny, T., Yantosca, R. M., Carouge, C. C., and Le Sager, P.: Nitrogen oxides and PAN in plumes from boreal fires during ARCTAS-B and their impact on ozone: an integrated analysis of aircraft and satellite observations, Atmos. Chem. Phys., 10, 9739-9760, doi:10.5194/acp-10-9739-2010, 2010.

Atkinson, R., Baulch, D. L., Cox, R. A., Crowley, J. N., Hampson, R. F., Hynes, R. G., Jenkin, M. E., Rossi, M. J., and Troe, J.: Evaluated kinetic and photochemical data for atmospheric chemistry: Volume III - gas phase reactions of inorganic halogens, Atmos. Chem. Phys., 7, 981-1191, doi:10.5194/acp-7-981-2007, 2007.

Auvray, M. and Bey, I.: Long-range transport to Europe: Seasonal variations and implications for the European ozone budget, J. Geophys. Res., 110, D11303, doi:10.1029/2004JD005503, 2005.
Barrie, L. A., Hoff, R. M., and Daggupaty, S. M.: The influence of mid-latitudinal pollution sources on haze in the Canadian Arctic, Atmos. Environ., 15, 1407-1419, doi:10.1016/00046981(81)90347-4, 1981.

Barrie, L. A., Bottenheim, J. W., Schnell, R. C., Crutzen, P. J., and Rasmussen, R. A.: Ozone destruction and photochemical reactions at polar sunrise in the lower Arctic atmosphere, Nature, 334, 138-141, doi:10.1038/334138a0, 1988.

Bey, I., Jacob, D. J., Yantosca, R. M., Logan, J. A., Field, B. D., Fiore, A. M., Li, Q., Liu, H. Y., Mickley, L. J., and Schultz, M. G.: Global modeling of tropospheric chemistry with assimilated meteorology: Model description and evaluation, J. Geophys. Res., 106, 23073-23095, doi:10.1029/2001JD000807, 2001.

Chen, L., Rabitz, H., Considine, D. B., Jackman, C. H., and Shorter, J. A.: Chemical reaction rate sensitivity and uncertainty in a twodimensional middle atmospheric ozone model, J. Geophys. Res., 102, 16201-16214, doi:10.1029/97JD00702, 1997.

Chen, S. and Brune, W. H.: Global sensitivity analysis of ozone production and $\mathrm{O}_{3}-\mathrm{NO}_{x}-\mathrm{VOC}$ limitation based on field data, Atmos. Environ., 55, 288-296, doi:10.1016/j.atmosenv.2012.03.061, 2012.

Chen, S., Brune, W. H., Oluwole, O. O., Kolb, C. E., Bacon, F., Li, G., and Rabitz, H.: Global sensitivity analysis of the regional atmospheric chemical mechanism: an application of random sampling-high dimensional model representation to urban oxidation chemistry, Environ. Sci. Technol., 46, 11162-11170, doi:10.1021/es301565w, 2012.

Emmons, L. K., Arnold, S. R., Monks, S. A., Huijnen, V., Tilmes, S., Law, K. S., Thomas, J. L., Raut, J.-C., Bouarar, I., Turquety, S., Long, Y., Duncan, B., Steenrod, S., Strode, S., Flemming, J., Mao, J., Langner, J., Thompson, A. M., Tarasick, D., Apel, E. C., Blake, D. R., Cohen, R. C., Dibb, J., Diskin, G. S., Fried, A., Hall, S. R., Huey, L. G., Weinheimer, A. J., Wisthaler, A., Mikoviny, T., Nowak, J., Peischl, J., Roberts, J. M., Ryerson, T., Warneke, C., and Helmig, D.: The POLARCAT Model Intercomparison Project (POLMIP): overview and evaluation with observations, Atmos. Chem. Phys., 15, 6721-6744, doi:10.5194/acp15-6721-2015, 2015.

Faloona, I. C., Tan, D., Lesher, R. L., Hazen, N. L., Frame, C. L., Simpas, J. B., Harder, H., Martinez, M., Carlo, P. D., Ren, X., and Brune, W. H.: A Laser-induced Fluorescence Instrument for Detecting Tropospheric $\mathrm{OH}$ and $\mathrm{HO}_{2}$ : Characteristics and Calibration, J. Atmos. Chem., 47, 139-167, doi:10.1023/B:JOCH.0000021036.53185.0e, 2004.

Feil, B., Kucherenko, S., and Shah, N.: Comparison of Monte Carlo and Quasi Monte Carlo Sampling Methods in High Dimensional Model Representation, in: First International Conference on Advances in System Simulation, 2009, SIMUL '09, 20-25 September 2009, IEEE, 12-17, doi:10.1109/SIMUL.2009.34, 2009.

Fiore, A. M., Jacob, D. J., Bey, I., Yantosca, R. M., Field, B. D., Fusco, A. C., and Wilkinson, J. G.: Background ozone over the United States in summer: Origin, trend, and contribution to pollution episodes, J. Geophys. Res., 107, ACH 11-1-11-25, doi:10.1029/2001JD000982, 2002.

Fiore, A. M., Horowitz, L. W., Purves, D. W., Levy, H., Evans, M. J., Wang, Y., Li, Q., and Yantosca, R. M.: Evaluating the contribution of changes in isoprene emissions to surface ozone trends 
over the eastern United States, J. Geophys. Res., 110, D12303, doi:10.1029/2004JD005485, 2005.

Fiore, A. M., Dentener, F. J., Wild, O., Cuvelier, C., Schultz, M. G., Hess, P., Textor, C., Schulz, M., Doherty, R. M., Horowitz, L. W., MacKenzie, I. A., Sanderson, M. G., Shindell, D. T., Stevenson, D. S., Szopa, S., Van Dingenen, R., Zeng, G., Atherton, C., Bergmann, D., Bey, I., Carmichael, G., Collins, W. J., Duncan, B. N., Faluvegi, G., Folberth, G., Gauss, M., Gong, S., Hauglustaine, D., Holloway, T., Isaksen, I. S. A., Jacob, D. J., Jonson, J. E., Kaminski, J. W., Keating, T. J., Lupu, A., Marmer, E., Montanaro, V., Park, R. J., Pitari, G., Pringle, K. J., Pyle, J. A., Schroeder, S., Vivanco, M. G., Wind, P., Wojcik, G., Wu, S., and Zuber, A.: Multimodel estimates of intercontinental sourcereceptor relationships for ozone pollution, J. Geophys. Res., 114, D04301, doi:10.1029/2008JD010816, 2009.

Fischer, E. V., Jacob, D. J., Yantosca, R. M., Sulprizio, M. P., Millet, D. B., Mao, J., Paulot, F., Singh, H. B., Roiger, A., Ries, L., Talbot, R. W., Dzepina, K., and Pandey Deolal, S.: Atmospheric peroxyacetyl nitrate (PAN): a global budget and source attribution, Atmos. Chem. Phys., 14, 2679-2698, doi:10.5194/acp-142679-2014, 2014.

Fisher, J. A., Jacob, D. J., Purdy, M. T., Kopacz, M., Le Sager, P., Carouge, C., Holmes, C. D., Yantosca, R. M., Batchelor, R. L., Strong, K., Diskin, G. S., Fuelberg, H. E., Holloway, J. S., Hyer, E. J., McMillan, W. W., Warner, J., Streets, D. G., Zhang, Q., Wang, Y., and $\mathrm{Wu}, \mathrm{S}$.: Source attribution and interannual variability of Arctic pollution in spring constrained by aircraft (ARCTAS, ARCPAC) and satellite (AIRS) observations of carbon monoxide, Atmos. Chem. Phys., 10, 977-996, doi:10.5194/acp10-977-2010, 2010.

Fuchs, H., Bohn, B., Hofzumahaus, A., Holland, F., Lu, K. D., Nehr, S., Rohrer, F., and Wahner, A.: Detection of $\mathrm{HO}_{2}$ by laserinduced fluorescence: calibration and interferences from $\mathrm{RO}_{2}$ radicals, Atmos. Meas. Tech., 4, 1209-1225, doi:10.5194/amt4-1209-2011, 2011.

Granier, C., Niemeier, U., Jungclaus, J. H., Emmons, L., Hess, P., Lamarque, J.-F., Walters, S., and Brasseur, G. P.: Ozone pollution from future ship traffic in the Arctic northern passages, Geophys. Res. Lett., 33, L13807, doi:10.1029/2006GL026180, 2006.

Guenther, A. B., Jiang, X., Heald, C. L., Sakulyanontvittaya, T., Duhl, T., Emmons, L. K., and Wang, X.: The Model of Emissions of Gases and Aerosols from Nature version 2.1 (MEGAN2.1): an extended and updated framework for modeling biogenic emissions, Geosci. Model Dev., 5, 1471-1492, doi:10.5194/gmd-51471-2012, 2012.

Guerova, G., Bey, I., Attié, J.-L., Martin, R. V., Cui, J., and Sprenger, M.: Impact of transatlantic transport episodes on summertime ozone in Europe, Atmos. Chem. Phys., 6, 2057-2072, doi:10.5194/acp-6-2057-2006, 2006.

Heald, C. L., Ridley, D. A., Kreidenweis, S. M., and Drury, E. E.: Satellite observations cap the atmospheric organic aerosol budget, Geophys. Res. Lett., 37, L24808, doi:10.1029/2010GL045095, 2010.

Jacob, D. J.: Chemistry of $\mathrm{OH}$ in remote clouds and its role in the production of formic acid and peroxymonosulfate, J. Geophys. Res., 91, 9807-9826, doi:10.1029/JD091iD09p09807, 1986.

Jacob, D. J.: Heterogeneous chemistry and tropospheric ozone, Atmos. Environ., 34, 2131-2159, doi:10.1016/S13522310(99)00462-8, 2000.
Jacob, D. J., Crawford, J. H., Maring, H., Clarke, A. D., Dibb, J. E., Emmons, L. K., Ferrare, R. A., Hostetler, C. A., Russell, P. B., Singh, H. B., Thompson, A. M., Shaw, G. E., McCauley, E., Pederson, J. R., and Fisher, J. A.: The Arctic Research of the Composition of the Troposphere from Aircraft and Satellites (ARCTAS) mission: design, execution, and first results, Atmos. Chem. Phys., 10, 5191-5212, doi:10.5194/acp-10-5191-2010, 2010.

Jacobson, M. Z. and Turco, R. P.: SMVGEAR: A sparse-matrix, vectorized gear code for atmospheric models, Atmos. Environ., 28, 273-284, doi:10.1016/1352-2310(94)90102-3, 1994.

Jaeglé, L., Steinberger, L., Martin, R. V., and Chance, K.: Global partitioning of $\mathrm{NO}_{x}$ sources using satellite observations: Relative roles of fossil fuel combustion, biomass burning and soil emissions, Faraday Discuss., 130, 407, doi:10.1039/b502128f, 2005.

Kalos, M. H. and Whitlock, P. A.: Monte Carlo Methods: Basics, J. Wiley \& Sons, New York, USA, 1986.

Kinnison, D. E., Brasseur, G. P., Walters, S., Garcia, R. R., Marsh, D. R., Sassi, F., Harvey, V. L., Randall, C. E., Emmons, L., Lamarque, J. F., Hess, P., Orlando, J. J., Tie, X. X., Randel, W., Pan, L. L., Gettelman, A., Granier, C., Diehl, T., Niemeier, U., and Simmons, A. J.: Sensitivity of chemical tracers to meteorological parameters in the MOZART-3 chemical transport model, J. Geophys. Res., 112, D20302, doi:10.1029/2006JD007879, 2007.

Koo, J.-H., Wang, Y., Kurosu, T. P., Chance, K., Rozanov, A., Richter, A., Oltmans, S. J., Thompson, A. M., Hair, J. W., Fenn, M. A., Weinheimer, A. J., Ryerson, T. B., Solberg, S., Huey, L. G., Liao, J., Dibb, J. E., Neuman, J. A., Nowak, J. B., Pierce, R. B., Natarajan, M., and Al-Saadi, J.: Characteristics of tropospheric ozone depletion events in the Arctic spring: analysis of the ARCTAS, ARCPAC, and ARCIONS measurements and satellite BrO observations, Atmos. Chem. Phys., 12, 9909-9922, doi:10.5194/acp-12-9909-2012, 2012.

Levy II., H.: Normal Atmosphere: Large Radical and Formaldehyde Concentrations Predicted, Science, 173, 141-143, doi:10.1126/science.173.3992.141, 1971.

Li, G., Rosenthal, C., and Rabitz, H.: High Dimensional Model Representations, J. Phys. Chem. A, 105, 7765-7777, doi:10.1021/jp010450t, 2001.

Li, G., Rabitz, H., Wang, S.-W., and Georgopoulos, P. G.: Correlation method for variance reduction of Monte Carlo integration in RS-HDMR, J. Comput. Chem., 24, 277-283, doi:10.1002/jcc.10172, 2003.

Li, G., Rabitz, H., Yelvington, P. E., Oluwole, O. O., Bacon, F., Kolb, C. E., and Schoendorf, J.: Global Sensitivity Analysis for Systems with Independent and/or Correlated Inputs, J. Phys. Chem. A, 114, 6022-6032, doi:10.1021/jp9096919, 2010.

Liaskos, C. E., Allen, D. J., and Pickering, K. E.: Sensitivity of tropical tropospheric composition to lightning $\mathrm{NO}_{\mathrm{x}}$ production as determined by replay simulations with GEOS-5, J. Geophys. Res.Atmos., 120, 8512-8534, doi:10.1002/2014JD022987, 2015.

Lin, S.-J. and Rood, R. B.: Multidimensional FluxForm Semi-Lagrangian Transport Schemes, Mon. Weather Rev., 124, 2046-2070, doi:10.1175/15200493(1996)124<2046:MFFSLT>2.0.CO;2, 1996.

Lu, X., Wang, Y.-P., Ziehn, T., and Dai, Y.: An efficient method for global parameter sensitivity analysis and its applications to the Australian community land surface 
model (CABLE), Agr. Forest Meteorol., 182-183, 292-303, doi:10.1016/j.agrformet.2013.04.003, 2013.

Mao, J., Jacob, D. J., Evans, M. J., Olson, J. R., Ren, X., Brune, W. H., Clair, J. M. St., Crounse, J. D., Spencer, K. M., Beaver, M. R., Wennberg, P. O., Cubison, M. J., Jimenez, J. L., Fried, A., Weibring, P., Walega, J. G., Hall, S. R., Weinheimer, A. J., Cohen, R. C., Chen, G., Crawford, J. H., McNaughton, C., Clarke, A. D., Jaeglé, L., Fisher, J. A., Yantosca, R. M., Le Sager, P., and Carouge, $\mathrm{C} .:$ Chemistry of hydrogen oxide radicals $\left(\mathrm{HO}_{\mathrm{x}}\right)$ in the Arctic troposphere in spring, Atmos. Chem. Phys., 10, 58235838, doi:10.5194/acp-10-5823-2010, 2010.

Mao, J., Ren, X., Zhang, L., Van Duin, D. M., Cohen, R. C., Park, J.-H., Goldstein, A. H., Paulot, F., Beaver, M. R., Crounse, J. D., Wennberg, P. O., DiGangi, J. P., Henry, S. B., Keutsch, F. N., Park, C., Schade, G. W., Wolfe, G. M., Thornton, J. A., and Brune, W. H.: Insights into hydroxyl measurements and atmospheric oxidation in a California forest, Atmos. Chem. Phys., 12, 8009-8020, doi:10.5194/acp-12-8009-2012, 2012.

Mao, J., Fan, S., Jacob, D. J., and Travis, K. R.: Radical loss in the atmosphere from $\mathrm{Cu}-\mathrm{Fe}$ redox coupling in aerosols, Atmos. Chem. Phys., 13, 509-519, doi:10.5194/acp-13-509-2013, 2013a.

Mao, J., Paulot, F., Jacob, D. J., Cohen, R. C., Crounse, J. D., Wennberg, P. O., Keller, C. A., Hudman, R. C., Barkley, M. P., and Horowitz, L. W.: Ozone and organic nitrates over the eastern United States: Sensitivity to isoprene chemistry, J. Geophys. Res.-Atmos., 118, 11256-11268, doi:10.1002/jgrd.50817, 2013 b.

Martin, R. V., Jacob, D. J., Yantosca, R. M., Chin, M., and Ginoux, P.: Global and regional decreases in tropospheric oxidants from photochemical effects of aerosols, J. Geophys. Res., 108, 4097, doi:10.1029/2002JD002622, 2003.

Martin, R. V., Sauvage, B., Folkins, I., Sioris, C. E., Boone, C., Bernath, P., and Ziemke, J.: Space-based constraints on the production of nitric oxide by lightning, J. Geophys. Res., 112, D09309, doi:10.1029/2006JD007831, 2007.

McLinden, C. A., Olsen, S. C., Hannegan, B., Wild, O., Prather, M. J., and Sundet, J.: Stratospheric ozone in 3-D models: A simple chemistry and the cross-tropopause flux, J. Geophys. Res., 105, 14653-14665, doi:10.1029/2000JD900124, 2000.

Miyazaki, K., Eskes, H. J., Sudo, K., and Zhang, C.: Global lightning $\mathrm{NO}_{\mathrm{x}}$ production estimated by an assimilation of multiple satellite data sets, Atmos. Chem. Phys., 14, 3277-3305, doi:10.5194/acp-14-3277-2014, 2014.

Morris, M. D.: Factorial Sampling Plans for Preliminary Computational Experiments, Technometrics, 33, 161-174, doi:10.1080/00401706.1991.10484804, 1991.

Olivier, J. G. J., Bouwman, A. F., van der Mass, C. W. M., Berdowski, J. J. M., Veldt, C., Bloos, J. P. J., Visschedijk, A. J. H., Zandveld, P. Y. J., and Haverlag, J. L.: Description of EDGAR version 2.0: a set of global emission inventories of greenhouse gases and ozone-depleting substances for all anthropogenic and most natural sources on a per country basis and on 1 degree x 1 degree grid, http://inis.iaea.org/Search/search.aspx? orig_q=RN:29006635, last access: 25 July 2016, 1996.

Ott, L. E., Bacmeister, J., Pawson, S., Pickering, K., Stenchikov, G., Suarez, M., Huntrieser, H., Loewenstein, M., Lopez, J., and Xueref-Remy, I.: Analysis of Convective Transport and Parameter Sensitivity in a Single Column Version of the Goddard Earth
Observation System, Version 5, General Circulation Model, J. Atmos. Sci., 66, 627-646, doi:10.1175/2008JAS2694.1, 2009.

Price, C. and Rind, D.: A simple lightning parameterization for calculating global lightning distributions, J. Geophys. Res., 97, 9919-9933, doi:10.1029/92JD00719, 1992.

Rabitz, H. and Aliş, O. F.: General foundations of highdimensional model representations, J. Math. Chem., 25, 197233, doi:10.1023/A:1019188517934, 1999.

Reinhart, W. and Millet, D.: Implementation of the RETRO anthropogenic emission inventory into the GEOS-Chem model, 1-11, http://wiki.seas.harvard.edu/geos-chem/images/4/49/GC_ RETRO_update_v831_final.pdf, last access: 8 September , 2016, 2011.

Ren, X., Mao, J., Brune, W. H., Cantrell, C. A., Mauldin III, R. L., Hornbrook, R. S., Kosciuch, E., Olson, J. R., Crawford, J. H., Chen, G., and Singh, H. B.: Airborne intercomparison of $\mathrm{HO}_{\mathrm{x}}$ measurements using laser-induced fluorescence and chemical ionization mass spectrometry during ARCTAS, Atmos. Meas. Tech., 5, 2025-2037, doi:10.5194/amt-5-2025-2012, 2012.

Saltelli, A., Ratto, M., Andres, T., Campolongo, F., Cariboni, J., Gatelli, D., Saisana, M., and Tarantola, S.: Global Sensitivity Analysis: The Primer, John Wiley \& Sons, Chichester, UK, 2008.

Sander, S., Abbatt, J., Barker, J., Burkholder, J., Friedl, R., Golden, D., Huie, R., Kolb, C., Kurylo, M., Moortgat, G., Orkin, V., and Wine, P.: Chemical Kinetics and Photochemical Data for Use in Atmospheric Studies, Evaluation No. 17, JPL Publication 10-6, Jet Propulsion Laboratory, Pasadena, 2011.

Sauvage, B., Martin, R. V., van Donkelaar, A., Liu, X., Chance, K., Jaeglé, L., Palmer, P. I., Wu, S., and Fu, T.-M.: Remote sensed and in situ constraints on processes affecting tropical tropospheric ozone, Atmos. Chem. Phys., 7, 815-838, doi:10.5194/acp-7-815-2007, 2007.

Schumann, U. and Huntrieser, H.: The global lightning-induced nitrogen oxides source, Atmos. Chem. Phys., 7, 3823-3907, doi:10.5194/acp-7-3823-2007, 2007.

Shindell, D. T., Faluvegi, G., Stevenson, D. S., Krol, M. C., Emmons, L. K., Lamarque, J.-F., Pétron, G., Dentener, F. J., Ellingsen, K., Schultz, M. G., Wild, O., Amann, M., Atherton, C. S., Bergmann, D. J., Bey, I., Butler, T., Cofala, J., Collins, W. J., Derwent, R. G., Doherty, R. M., Drevet, J., Eskes, H. J., Fiore, A. M., Gauss, M., Hauglustaine, D. A., Horowitz, L. W., Isaksen, I. S. A., Lawrence, M. G., Montanaro, V., Müller, J.-F., Pitari, G., Prather, M. J., Pyle, J. A., Rast, S., Rodriguez, J. M., Sanderson, M. G., Savage, N. H., Strahan, S. E., Sudo, K., Szopa, S., Unger, N., van Noije, T. P. C., and Zeng, G.: Multimodel simulations of carbon monoxide: Comparison with observations and projected near-future changes, J. Geophys. Res., 111, D19306, doi:10.1029/2006JD007100, 2006.

Simpson, W. R., von Glasow, R., Riedel, K., Anderson, P., Ariya, P., Bottenheim, J., Burrows, J., Carpenter, L. J., Frieß, U., Goodsite, M. E., Heard, D., Hutterli, M., Jacobi, H.-W., Kaleschke, L., Neff, B., Plane, J., Platt, U., Richter, A., Roscoe, H., Sander, R., Shepson, P., Sodeau, J., Steffen, A., Wagner, T., and Wolff, E.: Halogens and their role in polar boundary-layer ozone depletion, Atmos. Chem. Phys., 7, 4375-4418, doi:10.5194/acp-74375-2007, 2007.

Sobol, I. M.: Uniformly distributed sequences with an additional uniform property, USSR Comp. Math. Math+, 16, 236-242, doi:10.1016/0041-5553(76)90154-3, 1976. 
Stewart, R. W. and Thompson, A. M.: Kinetic data imprecisions in photochemical rate calculations: Means, medians, and temperature dependence, J. Geophys. Res., 101, 20953-20964, doi:10.1029/96JD01708, 1996.

Stohl, A.: Characteristics of atmospheric transport into the Arctic troposphere, J. Geophys. Res., 111, D11306, doi:10.1029/2005JD006888, 2006.

Thornton, J. A., Jaeglé, L., and McNeill, V. F.: Assessing known pathways for $\mathrm{HO}_{2}$ loss in aqueous atmospheric aerosols: Regional and global impacts on tropospheric oxidants, J. Geophys. Res., 113, D05303, doi:10.1029/2007JD009236, 2008.

van der Werf, G. R., Randerson, J. T., Giglio, L., Collatz, G. J., Mu, M., Kasibhatla, P. S., Morton, D. C., DeFries, R. S., Jin, Y., and van Leeuwen, T. T.: Global fire emissions and the contribution of deforestation, savanna, forest, agricultural, and peat fires (19972009), Atmos. Chem. Phys., 10, 11707-11735, doi:10.5194/acp10-11707-2010, 2010.

Vinken, G. C. M., Boersma, K. F., Maasakkers, J. D., Adon, M., and Martin, R. V.: Worldwide biogenic soil $\mathrm{NO}_{\mathrm{x}}$ emissions inferred from OMI $\mathrm{NO}_{2}$ observations, Atmos. Chem. Phys., 14, 1036310381, doi:10.5194/acp-14-10363-2014, 2014.

Weinheimer, A. J., Walega, J. G., Ridley, B. A., Gary, B. L., Blake, D. R., Blake, N. J., Rowland, F. S., Sachse, G. W., Anderson, B. E., and Collins, J. E.: Meridional distributions of $\mathrm{NO}_{\mathrm{x}}, \mathrm{NO}_{\mathrm{y}}$, and other species in the lower stratosphere and upper troposphere during AASE II, Geophys. Res. Lett., 21, 2583-2586, doi:10.1029/94GL01897, 1994.

Whalley, L. K., Stone, D., George, I. J., Mertes, S., van Pinxteren, D., Tilgner, A., Herrmann, H., Evans, M. J., and Heard, D. E.: The influence of clouds on radical concentrations: observations and modelling studies of HOx during the Hill Cap Cloud Thuringia (HCCT) campaign in 2010, Atmos. Chem. Phys., 15, 3289-3301, doi:10.5194/acp-15-3289-2015, 2015.
Wild, O. and Prather, M. J.: Global tropospheric ozone modeling: Quantifying errors due to grid resolution, J. Geophys. Res., 111, D11305, doi:10.1029/2005JD006605, 2006.

Wild, O., Zhu, X., and Prather, M. J.: Fast-J: Accurate Simulation of In- and Below-Cloud Photolysis in Tropospheric Chemical Models, J. Atmos. Chem., 37, 245-282, doi:10.1023/A:1006415919030, 2000.

Wu, S., Mickley, L. J., Jacob, D. J., Logan, J. A., Yantosca, R. M., and Rind, D.: Why are there large differences between models in global budgets of tropospheric ozone?, J. Geophys. Res., 112, D05302, doi:10.1029/2006JD007801, 2007.

Wu, S., Duncan, B. N., Jacob, D. J., Fiore, A. M., and Wild, O.: Chemical nonlinearities in relating intercontinental ozone pollution to anthropogenic emissions, Geophys. Res. Lett., 36, L05806, doi:10.1029/2008GL036607, 2009.

Ziehn, T. and Tomlin, A. S.: Global sensitivity analysis of a 3D street canyon model - Part I: The development of high dimensional model representations, Atmos. Environ., 42, 1857-1873, doi:10.1016/j.atmosenv.2007.11.018, 2008a.

Ziehn, T. and Tomlin, A. S.: A global sensitivity study of sulfur chemistry in a premixed methane flame model using HDMR, Int. J. Chem. Kinet., 40, 742-753, doi:10.1002/kin.20367, 2008b.

Ziehn, T. and Tomlin, A. S.: GUI-HDMR - A software tool for global sensitivity analysis of complex models, Environ. Modell. Softw., 24, 775-785, doi:10.1016/j.envsoft.2008.12.002, 2009.

Ziehn, T., Hughes, K. J., Griffiths, J. F., Porter, R., and Tomlin, A. S.: A global sensitivity study of cyclohexane oxidation under low temperature fuel-rich conditions using HDMR methods, Combust. Theor. Model., 13, 589-605, doi:10.1080/13647830902878398, 2009. 